\title{
Experimental Study of the Corrosiveness of Ternary Blends of Biodiesel Fuel
}

OPEN ACCESS

Edited by:

Mukesh Kumar Awasthi,

Northwest A\&F University, China

Reviewed by:

Pau Loke Show,

University of Nottingham Malaysia

Campus, Malaysia

Baskar Gurunathan,

St. Joseph's College of Engineering,

India

Kit Wayne Chew,

Xiamen University, Malaysia, Malaysia

*Correspondence:

Jassinnee Milano

jassinneemilano.jm@gmail.com

A. S. Silitonga

ardinsu@yahoo.co.id

Specialty section: This article was submitted to

Bioenergy and Biofuels,

a section of the journal

Frontiers in Energy Research

Received: 17 September 2021

Accepted: 20 October 2021

Published: 17 November 2021

Citation:

Milano J, Umar $H$, Shamsuddin $A H$, Silitonga AS, Irfan $O M$, Sebayang $A H$,

Fattah IMR and Mofijur M (2021)

Experimental Study of the

Corrosiveness of Ternary Blends of

Biodiesel Fuel.

Front. Energy Res. 9:778801.

doi: 10.3389/fenrg.2021.778801
Jassinnee Milano ${ }^{1 *}$, Hamdani Umar ${ }^{2}$, A. H. Shamsuddin ${ }^{1}$, A. S. Silitonga ${ }^{3,4 *}$, Osama M. Irfan ${ }^{5}$, A. H. Sebayang ${ }^{3,4}$, I. M. Rizwanul Fattah ${ }^{6}$ and M. Mofijur ${ }^{6,7}$

${ }^{1}$ Institute of Sustainable Energy, Universiti Tenaga Nasional, Kajang, Malaysia, ${ }^{2}$ Department of Mechanical Engineering, Faculty of Engineering, Universitas Syiah Kuala, Banda Aceh, Indonesia, ${ }^{3}$ Department of Mechanical Engineering, Politeknik Negeri Medan, Medan, Indonesia, ${ }^{4}$ Centre of Renewable Energy, Department of Mechanical Engineering, Politeknik Negeri Medan, Medan, Indonesia, ${ }^{5}$ Department of Mechanical Engineering, College of Engineering, Qassim University, Qassim, Saudi Arabia, ${ }^{6}$ Centre for Green Technology, Faculty of Engineering and IT, University of Technology Sydney, Sydney, NSW, Australia, ${ }^{7}$ Mechanical Engineering Department, Prince Mohammad Bin Fahd University, Al Khobar, Saudi Arabia

Biodiesel is an alternative renewable resource to petroleum-based diesel. The aim of using biodiesel is to reduce environmental pollution and combat global warming. Biodiesel application in compression ignition engines has shown its compatibility with better combustion characteristics and high engine performance. Many advantages can be obtained by using biodiesel, including reducing exhaust gases, reducing air toxicity, providing energy security, and being biodegradable. However, biodiesel's disadvantage involves oxidation stability, corrosion, degradation, and compatibility with other metallic materials. The present study investigates the corrosive behavior of the ternary blend (waste cooking-Calophyllum inophyllum biodiesel-diesel) fuel that occurs in contact with mild steel and stainless steel 316. The observation study for mild steel and stainless steel 316 material under the static immersion method was performed for $7,200 \mathrm{~h}$ and $14,400 \mathrm{~h}$, respectively, at room temperature $\left(25^{\circ} \mathrm{C}-30^{\circ} \mathrm{C}\right)$. In every 720 and $1,440 \mathrm{~h}$ of immersion time, the coupon's profile was analyzed by scanning electron microscopy (SEM)/electron-dispersive spectrometer (EDS), and the mass loss was observed, for corrosivity investigation. Based on the obtained results, the average corrosion rate of mild steel and stainless steel 316 is 0.6257 and $0.0472 \mathrm{~nm} /$ year at $7,200 \mathrm{~h}$, respectively; the difference in corrosion rate for these metallic materials is approximately $92.46 \%$. The degradation of the fuel properties such as kinematic viscosity, density, refractive index, and acid value was monitored. In this study, stainless steel 316 was more resistant to corrosion attack with some micro pitting and showed better compatibility with the ternary blend than mild steel. The regression analysis and the correlation of corrosion rate were studied.

Keywords: corrosion analysis, waste cooking oil, Calophyllum inophyllum, diesel fuel, fuel properties analysis, automotive components 


\section{HIGHLIGHTS}

- Degradation of the biodiesel produced from waste cooking oil and Calophyllum inophyllum was observed.

- Corrosion on stainless steel 316 was initiated after being immersed for 120 days (B25 and B30).

- Mild steel started to form metal oxides after being immersed in the fuel blend.

- Worn surface characteristics of coupons were examined using SEM and EDS.

- Correlation between physicochemical properties and corrosion was studied.

\section{INTRODUCTION}

The world faces two detrimental challenges: an energy crisis and environmental pollution (Mofijur et al., 2013b). Biofuel is a suitable alternative energy source for power generation and transportation fuel to reduce the use of fossil fuels (Mofijur et al., 2013a). Biofuel can reduce the detrimental impact of global warming and is assessed to support the future energy demand (Sarin et al., 2007; Brennan and Owende, 2010; Silitonga et al., 2019). Biofuel is classified into four types of renewable feedstocks (Mat Aron et al., 2020). First-generation biofuel is synthesized from edible feedstocks such as palm oil, sunflower oil, soyabean oil, rapeseed oil, and animal fat. Second-generation biofuel is retained from non-edible feedstocks such as Calophyllum inophyllum (Damanik et al., 2017), Ceiba pentandra (Kusumo et al., 2017), Reutealis trisperma (Riayatsyah et al., 2017), Cascabela ovata (Sánchez-Arreola et al., 2019), and waste cooking oil (Milano et al., 2018b). Second-generation biofuels are more favorable, as they are not competing with food supply and arable land and have a lower environmental impact than first-generation biofuel (Moser, 2009; Siddiki et al., 2022). Third-generation biofuels are produced from microalgae biomass (Chia et al., 2018) that requires a large amount of freshwater and nutrients (Milano et al., 2016). Biofuel extracted from microalgae has high volatility compared with first- and second-generation biofuels (Goh et al., 2019). Biooil extraction requires high-energy input and intensification process (Lee et al., 2020). Fourth-generation biofuel aimed to modify the genetics of microalgae to achieve high-density microalgae and increase biofuel productivity.

However, the genetic modification technology for microalgae is still in the infant stage and lacks genetic information (Mat Aron et al., 2020). Biofuel is a renewable fuel for diesel engine. Biofuel differs from diesel in chemical compounds and synthesis processes but possesses similar fuel characteristics. Biofuels can be used directly or blended with diesel for compression ignition engines (Folayan and Anawe, 2019). However, there are a few drawbacks of using biofuels. It causes metallic corrosion in a significant part of the engine, including fuel pump, filter, lines, injectors, injection cylinders, tank, gaskets, piston, piston rings, and fasteners when it is in contact with the biofuels (Gulzar et al., 2016). The metallic materials used to manufacture the above engine parts were steel, copper, aluminum, stainless steels, and alloys (Singh et al., 2012). Polymers also degraded under the influence of biofuels such as fuel hose, engine mount, engine seals, rubber seals, O-rings. Corrosion will lower the engine performance, increase fuel consumption, and increase the wear rate of the engine parts (Wei and Wang, 2021). Hence, the compatibility of biofuels with metallic materials becomes the manufacturer's major concern, as it determines the durability of the engine and failure of the mechanical parts. Besides, it also causes significant problems in fuel transport and storage facilities, as steel is a popular material used in industrial applications (Komariah et al., 2021).

Metallic material corrosion, biofuel degradation, and fuel contamination have become inevitable problems in the biofuel industry. Corrosion on metallic materials commonly used for engine parts manufacturing has already been studied, but the corrosion problems still remain. The metallic materials that have been investigated were copper (Fazal et al., 2013; Cestari et al., 2021), bronze (Haseeb et al., 2010), brass (Aquino et al., 2012), cast iron (Fazal et al., 2012), carbon steel (Fernandes et al., 2019), mild steel (Fazal et al., 2011), aluminum (Kugelmeier et al., 2021), and stainless steel (Fazal et al., 2010; Hu et al., 2012). The investigated biofuels were derived from palm oil (Jin et al., 2015), canola oil (Díaz-Ballote et al., 2009), sunflower oil (Cursaru et al., 2014), ghee butter (Ononiwu et al., 2015), rice husk (Lu et al., 2008), soyabean oil (Román et al., 2016), Salvadora oil (Kaul et al., 2007), rapeseed oil (Hu et al., 2012), and poultry fat (Geller et al., 2008). Corrosion behavior was evaluated by static immersion test or electrochemical method (Wang et al., 2012). Most researchers choose to perform a static immersion test by immersing the metallic specimen in biofuels with pure diesel, biodiesel, or blended diesel with biodiesel in various proportions. Several researchers used the electrochemical method to determine the corrosion rate of studied metallic materials, which can obtain results at a shorter time than the immersion test (Shehzad et al., 2021).

However, the calculated corrosion rate might differ from the actual value. The reliability and reality of the results are questionable. The corrosion characteristic of the specimen was analyzed using scanning electron microscopy (SEM) (Alves et al., 2019), electron-dispersive spectrometer (EDS), X-ray diffraction (XRD) (Cursaru et al., 2014), and transmission electron microscopy (TEM) (Yang et al., 2018); these advanced instruments are able to capture and analyze the morphology of the corrosion as well as characterize the microstructure of metallic material, then revealing the nature and extent of corrosion. The biofuel degradation may also induce corrosion in the metallic materials. Hence, the degradation of biofuels has been the precedence of the feasibility of plant-derived biofuels. Biofuels' properties determine the compatibility with metallic and polymer materials, challenging the biodiesel's sustainability. The foremost biofuel properties that needed to be observed and controlled were oxidation stability (Supriyono et al., 2015), thermal stability (Jain and Sharma, 2011; Silva de Sousa et al., 2020), and storage stability (Komariah et al., 2021). The fuel stability properties can be determined by evaluating the changes in viscosity, density, acid value, water contents, cetane number, biofuel's color, and synergistic index (Lin et al., 2019). Fuel 
degradation can be measured using Fourier transform infrared spectroscopy (FTIR) spectra to observe the changes in height/area of a specific peak (Alves et al., 2019). Oxidation stability of the biodiesel depends on the surrounding conditions such as oxygen concentration and light and moisture exposure (Hazrat et al., 2021). Oxidation of biofuels will cause fuel contamination, such as the formation of aldehydes, carboxylic acids, hydrocarbon, ketones, polymers, and others (Monirul et al., 2015). These byproducts will cause harmful emissions and insoluble particles that will clog the fuel filters and cause challenges to the fuel lines.

Waste cooking vegetable oil is an economical (Issariyakul and Dalai, 2014) and sustainable source (Khatiwada et al., 2018) for biofuel production (Zahan and Kano, 2018). However, waste cooking oil poses a significant challenge because of its high free fatty acid (FFA), water, and impurities. The physicochemical properties of waste cooking biodiesel were improved by blending it with C. inophyllum oil at a ratio of 7:3, named W70CI30. The blended fuel produces high-performance biofuel (Zahan and Kano, 2018) with high biodiesel yields, good oxidation stability, and better cold flow properties (Milano et al., 2018a). Microwave technologies were employed to shorten the time requested for biodiesel synthesis, boost biodiesel yield, and produce superior-quality biodiesel [higher fatty acid methyl ester (FAME) content with low glycerol and glyceride composition]. The study was conducted to examine the compatibility of various metallic materials toward W70CI30 blended fuels. The hybrid biodiesel blends with diesel to form ternary fuel blends with various proportions such as B5, B10, B15, B20, B25, and B30. Static immersion method was employed to initiate corrosivity of mild steel and stainless steel 316 . Both experiments were performed at $25^{\circ} \mathrm{C}-30^{\circ} \mathrm{C}$ (room temperature) for 7,200 h (300 days) and 14,400 h (600 days), respectively, for mild steel and stainless steel 316. An overview of the corrosion behavior of stainless steel 316 can be obtained by extending the immersion time beyond mild steel. Stainless steel 316 is more corrosion resistant, and extending the immersion period will deliver a more precise knowledge of its compatibility with the ternary blend. SEM/EDS was adopted to examine the corrosion behavior of the metallic material. The physicochemical properties of biodiesel and biodiesel-diesel blended fuel before and after the immersion period were measured. The properties measured and observed were kinematic viscosity, density, refractive index, and acid value. These properties were observed to determine the degradation of the biofuel associated with metallic material and biofuel's concentration. The correlation between physicochemical characteristics of biofuels and metallic material corrosivity is evaluated. Regression analysis for both metallic materials was studied.

To our knowledge, based on the literature, there are no researchers who performed a corrosion study on biodiesel produced from the intensification process, i.e., microwave irradiation-assisted alkaline-catalyzed transesterification on mild steel and stainless steel 316. Therefore, this study evaluates the compatibility and corrosion behavior of mild steel and stainless steel 316 in contact with B5-B30 fuel blends. The blends were selected by considering the fuel blends that are already being used in many countries
(B5-B20). Some countries planned to raise the blend rate to B30 (Brazil) (Kugelmeier et al., 2021), China (B30) (Kim, 2019), and Indonesia (B30) (Halimatussadiah et al., 2021). This study was conducted to understand the behavior of the engine parts in the biofuel blends. The results obtained in this study will provide more information to understand better the compatibility of metal or automotive material in contact with biodiesel-diesel fuel blends. The corrosion rate and the mechanism were determined, and further action can be taken to mitigate or prevent further corrosion damage on metallic material exposed to biofuel. In addition, further information on the effect of using non-edible biodiesel derived from waste cooking oil and $C$. inophyllum oil was obtained. The corrosion behavior and investigated result can be used to select suitable materials to form a biofuel storage tank with long service life according to various biofuel concentrations. Moreover, the result can help determine the proper storage time, transport, and utilization of biofuels. At the same time, it can mitigate corrosion problems worldwide, and timely measures can be taken to prevent or minimize costly damage.

\section{MATERIALS AND METHODS}

\section{Materials}

The non-edible feedstocks named C. inophyllum (CI) raw oils were purchased from Koperasi Jarak Lestari, Kebumen, Central Java, Indonesia. Waste cooking (WC) vegetable oil was collected from various restaurants in the food and beverage industry. The following chemicals were used for biodiesel production and corrosion analysis: 1) methanol (brand: Friendemann Schmidt, purity: $99.9 \%$, packaging: $4 \mathrm{~L}$, grade: ACS reagent), 2) sulfuric acid (brand: Friendemann Schmidt, packaging: $2.5 \mathrm{~L}$ purity: 95\%-97\%), 3) ortho-phosphoric acid (brand: Merck, packaging: $2.5 \mathrm{~L}$, purity: $85 \%$ ), 4) potassium hydroxide pellets (brand: Merck, packaging: $1 \mathrm{~kg}$, purity: 99\%), 5) acetone (brand: Fisher Scientific, purity: $>99.5 \%$, packaging: $1 \mathrm{~L}$, grade: ACS reagent), 6) toluene (brand: Sigma-Aldrich, packaging: $2 \mathrm{~L}$, purity: >99.8\%), 7) FAME mix $\mathrm{C}_{8}-\mathrm{C}_{24}$, (brand: Sigma-Aldrich, packaging: $100 \mathrm{mg}$, grade: analytical standard), 8) methyl nonadecanoate, $\mathrm{C}_{19}$ (brand: Sigma-Aldrich, packaging: $5 \mathrm{~g}$, purity: >99.5\%), 9) 1,2,4-butanetriol (brand: Agilent Technologies, packaging: $5 \mathrm{ml}$, concentration: $1,000 \mu \mathrm{g} / \mathrm{ml}$ in pyridine, P/N: 5982-0024), (10) Glycerol calibration kit 5 (brand: Agilent Technologies, packaging: $1 \mathrm{ml}, \mathrm{P} / \mathrm{N}$ : G344085028), 11) N-methyl-N-(trimethylsilyl)trifluoroacetamide (MSTFA) kit (brand: Agilent Technologies, packaging: $1 \mathrm{ml} \times$ 10, concentration: $100 \%, \mathrm{P} / \mathrm{N}: 5190-1407)$, 12) Monoglycerides calibration kit (brand: Agilent Technologies, concentration: 1Oleoyl-rac-glycerol-10,000 $\mu \mathrm{g} / \mathrm{ml}, \mathrm{Dl}$-alpha-palmitin-10,000 $\mu \mathrm{g} /$ $\mathrm{ml}$, and Monostearin-10,000 $\mu \mathrm{g} / \mathrm{ml}$, packaging: $1 \mathrm{ml}, \mathrm{P} / \mathrm{N}: 5190-$ 1410), 13) Glycerides stock solution in THF (brand: Agilent Technologies, concentration: monononadecanoin-2.5 $\mathrm{mg} / \mathrm{ml}$, dinonadecanoin-2.5 mg/ml, glyceryl trinonadecanoate- $2.5 \mathrm{mg} /$ ml, packaging: $2 \mathrm{ml}, \mathrm{P} / \mathrm{N}$ : G3440-85018), 14) Pyridine (brand: Sigma-Aldrich, packaging: $100 \mathrm{ml}$, purity: $\geq 99 \%$ ), 15) Heptane (brand: Fisher Scientific, packaging: $1 \mathrm{~L}$, purity: $>96 \%$, grade: 
TABLE 1 | Mild steel and stainless steel 316 compositions.

\begin{tabular}{|c|c|c|c|}
\hline Materials Composition & $\%$ & $\begin{array}{c}\text { Mild steel, C: } \\
\text { 0.25, Si: } 0.03 \text {, } \\
\text { Mn:0.4, P: 0.01, } \\
\text { S: } 0.02, \mathrm{Ni}: \\
0.025, \mathrm{Al}: 0.126 \text {, } \\
\text { Cu: } 0.036, \mathrm{Fe}: \\
99.103\end{array}$ & $\begin{array}{c}\text { Stainless steel type } \\
316 \text { C: } 0.08, \\
\text { Mn: } 2, \mathrm{Si}: \\
\text { 1, P: } 0.045, \\
\text { S: } 0.03, \mathrm{Cr}: 18, \\
\text { Ni: } 14, \mathrm{Mo:} \\
\text { 3, Fe: } 61.845\end{array}$ \\
\hline Outer diameter & $\mathrm{mm}$ & 16 & 18 \\
\hline Inner diameter & $\mathrm{mm}$ & 8.4 & 8.5 \\
\hline Thickness & $\mathrm{mm}$ & 1.2 & 1.2 \\
\hline
\end{tabular}

Mobile phase for HPLC applications), and 16) THF (brand: Sigma-Aldrich, packaging: $100 \mathrm{ml}$, purity: $\geq 99.89 \%$ ).

\section{Materials Used for Corrosiveness Investigation Mild Steel}

In this study, the specimens used were mild steel with an outer diameter of $16 \mathrm{~mm}$, an inner diameter of $8.4 \mathrm{~mm}$, and a thickness of $1.2 \mathrm{~mm}$. The inner circle of the specimen serves to hang the specimen during testing corrosion. Before the immersion, the specimen was selected by inspection, then mechanically sanded with 400-1,200 grit sandpaper, then washed with acetone and toluene. Finally, the specimens were dried in an oven, and the initial weight was recorded using a precision balance with four decimal accuracies (Mettler Toledo, AB204). The composition of mild steel is shown in Table 1. After specified immersion time, the specimen was collected and rinsed using acetone and toluene, then dried in an oven. The morphology and composition of the corrosion on the specimen are observed using SEM-EDS. Then, the corrosion surface of the specimen will be rubbed using abrasive brushes to remove the corroded spot. Then, the specimen was washed using acetone and dried in an oven, and the final weight was recorded for corrosion rate measurement.

\section{Stainless Steel 316}

Besides mild steel, stainless steel A4 316 was chosen in this study for corrosion investigation, and these specimens were also purchased from Advance Bolts Supplier Sdn Bhd. Flat stainless steel with an outer diameter of $18 \mathrm{~mm}$, an inner diameter of 8.5 $\mathrm{mm}$, and a thickness of $1.2 \mathrm{~mm}$ was used. The specimens were treated the same as the mild steel. The inner circle of the specimen serves to hang the specimen during testing for corrosion. Before the immersion, the specimen was selected by inspection and washed with acetone and toluene. Finally, the specimens were dried in an oven, and the initial weight of the specimens was recorded. The composition of stainless steel is shown in Table 1.

\section{Methods}

This study is performed to investigate the corrosion on mild steel and stainless steel 316 for a blending mixture of biodiesel produced from waste cooking oil blended with C. inophyllum oil. Corrosion test was conducted for mild steel with the observation time up to 10 months, while the observation time for stainless steel 316 was much longer, up to 20 months. The observation was prolonged further due to stainless steel 316 being more corrosive resistant than mild steel. After obtaining the corrosion rate, the surface morphology was assessed to observe the corrosiveness of the metallic specimen. Furthermore, the degradation of the blended biodiesel immersed with the specimen was observed. Lastly, the statistical analysis was performed to study the correlation between variables and the corrosion rate, and regression analysis was developed in this study.

\section{Esterification and Transesterification Processes for Biodiesel Production}

A double jacketed reactor was used to produce esterified WC70CI30 [70 $(\mathrm{v} / \mathrm{v}) \%$ of waste cooking vegetable oil $+30(\mathrm{v} /$ v) $\%$ of $C$. inophyllum oil] oil. The FFA content of the WC70CI30 is $9.92(\mathrm{w} / \mathrm{w}) \%$, which is highly undesirable because it will lead to low methyl ester yields due to saponification during the transesterification process. Therefore, in order to attain lower than $2 \%$ of FFA content, WC70CI30 was esterified using the following process parameters: 1) methanol/oil ratio: $70(\mathrm{v} / \mathrm{v}) \%, 2)$ $\mathrm{H}_{2} \mathrm{SO}_{4}$ concentration: $\left.1.5(\mathrm{v} / \mathrm{v}) \%, 3\right)$ reaction temperature: $60^{\circ} \mathrm{C}$, 4) reaction time: $2 \mathrm{~h}$, and 5) stirring speed: $1,500 \mathrm{rpm}$. The FFA content of the esterified oil was found to be $1.50(\mathrm{w} / \mathrm{w}) \%$, which is practically favorable in terms of the pretreatment process (Milano et al., 2018b).

Anton Paar Monowave 400 high-performance microwave reactor with Autosampler MAS24 was used for the microwave irradiation-assisted alkaline-catalyzed transesterification, where the esterified W70CI30 oil was converted into FAME. The optimized parameters for the transesterification process are 1) methanol/oil ratio: $59.60(\mathrm{v} / \mathrm{v}) \%, 2) \mathrm{KOH}$ catalyst concentration: $0.774(\mathrm{w} / \mathrm{w}) \%, 3)$ stirring speed: $600 \mathrm{rpm}, 4)$ reaction time 7.15 min, and 5) reaction temperature: $100^{\circ} \mathrm{C}$ (Milano et al., 2018a). The methyl ester yield produced by using the microwave reactor is $97.65(\mathrm{w} / \mathrm{w}) \%$. The equipment used to measure the physicochemical properties of biodiesel is shown in Table 2 . The properties of the biodiesel produced in this study are tabulated in Table 3, which all conforms to the specification stipulated in EN 14214 and ASTM D 6751 method.

\section{Blending Ratio}

The blending fuel B5 was prepared by blending $5(\mathrm{v} / \mathrm{v}) \%$ of W70CI30 biodiesel with $95(\mathrm{v} / \mathrm{v}) \%$ of diesel fuel. The other blending fuels were blended based on the ratios of $10,15,20$, 25 , and $30(\mathrm{v} / \mathrm{v}) \%$ of W70CI30 biodiesel with diesel fuel, named $\mathrm{B} 10, \mathrm{~B} 15, \mathrm{~B} 20, \mathrm{~B} 25$, and B30 accordingly. Then, the physicochemical properties of the biodiesel-diesel fuel blends are measured, and the results are presented in Table 4.

\section{Corrosion Test}

A corrosion test was conducted by static immersion tests on the specimens at $25^{\circ} \mathrm{C}-30^{\circ} \mathrm{C}$ (room temperature) for $7,200 \mathrm{~h}(300$ days) and 14,400 h (600 days) for mild steel and stainless steel 316, respectively. Metal specimens (mild steel and stainless steel) were hanged using Teflon thread separately and placed in the fuel mixture of biodiesel-diesel fuel blends. The weight loss during 
TABLE 2 | List of equipment used to measure the physicochemical properties of the W70Cl 30 biodiesel and the blending fuel.

\section{Property}

Kinematic viscosity at $40^{\circ} \mathrm{C}$

Density at $15^{\circ} \mathrm{C}$

Heating value

Acid value

Oxidation stability at $110^{\circ} \mathrm{C}$

Flash point

Cold filter plugging point

Cloud point and pour point

Copper strip corrosion

Conradson carbon residue

Refractive index

Sulfur content

FAME

Glycerides and Glycerol

\section{Equipment}

Stabinger viscometer ${ }^{\mathrm{TM}}$ SVM $3000^{\mathrm{TM}}$ (Anton Paar $\mathrm{GmbH}$, Austria)

DM40 LiquiPhysics ${ }^{\mathrm{TM}}$ Excellence density meter (Mettler Toledo, USA)

6200 Isoperibol calorimeter (Parr Instrument Company, USA)

Rondo 20 Automated titrator (Mettler Toledo, USA)

873 Biodiesel Rancimat (115 V) (Metrohm AG, Switzerland)

PMA 5 Pensky-Martens flash point tester (Anton Paar GmbH, Austria)

Callisto 100 Cold filter plugging point tester (Anton Paar GmbH, Austria)

NTE 450 Fully automated cloud and pour point tester (Normalab France SAS)

Seta copper corrosion bath (Part no.: 11,300-0, Stanhope-Seta, UK)

NMC 440 Fully automatic micro Conradson tester (Normalab France SAS)

Refractometer (Mettler Toledo, USA)

Multi EA 5000 (Analytik Jena, USA)

Agilent 7890A Gas chromatograph - FID (Agilent Technologies Inc., USA)

Agilent 7890A Gas chromatograph-Cool on-column (Agilent Technologies Inc., USA)

TABLE 3 | Physicochemical properties of biodiesel produced from microwave irradiation-assisted alkaline-catalyzed transesterification.

Property

Kinematic viscosity at $40^{\circ} \mathrm{C}$

Density at $15^{\circ} \mathrm{C}$

Acid value

Heating value

Oxidation stability at $110^{\circ} \mathrm{C}$

Flashpoint

Pour point

Cloud point

Cold filter plugging point

Copper strip corrosion

Sulfur content

Conradson carbon residue

FAME content

Linolenic methyl ester content

Methanol content

Monoglycerides

Diglycerides

Triglycerides

Free glycerol

Total glycerol
Unit

Microwave irradiation-assisted alkaline-catalyzed transesterification

$\mathrm{mm}^{2} / \mathrm{s}$

$\mathrm{kg} / \mathrm{m}^{3}$

$\mathrm{mg} \mathrm{KOH} / \mathrm{g}$

$\mathrm{MJ} / \mathrm{kg}$

$\mathrm{h}$

${ }^{\circ} \mathrm{C}$

${ }^{\circ} \mathrm{C}$

${ }^{\circ} \mathrm{C}$

${ }^{\circ} \mathrm{C}$

-

ppm

(w/w)\%

(w/w)\%

(w/w) \%

(w/W) \%

(w/W) \%

(w/w) \%

(w/W) \%

(W/W) \%

(w/w) \%
4.72

861.8

0.46

41.35

18.03

160.5

2

2

1

$1 a$

3.32

0.022

98.94

0.56

0.03

0.333

0.064

0.142

0.016

0.125

TABLE 4 | Properties of W70Cl30 biodiesel blend with diesel fuel.

Property

W70Cl30 biodiesel-diesel blend

\begin{tabular}{|c|c|c|c|c|c|c|c|c|c|}
\hline & \\
\hline & unit & $\begin{array}{l}\text { ASTM } \\
\text { D6751 }\end{array}$ & EN14214 & B5 & B10 & B15 & B20 & B25 & B30 \\
\hline Kinematic viscosity at $40^{\circ} \mathrm{C}$ & $\mathrm{mm}^{2} / \mathrm{s}$ & $1.9-6.0$ & $3.5-5.0$ & 3.3248 & 3.358 & 3.4079 & 3.4781 & 3.5171 & 3.6162 \\
\hline Dynamic viscosity at $40^{\circ} \mathrm{C}$ & mPa.s & - & - & 2.7718 & 2.8037 & 2.8499 & 2.9143 & 2.9513 & 3.0407 \\
\hline Density at $40^{\circ} \mathrm{C}$ & $\mathrm{kg} / \mathrm{m}^{3}$ & - & - & 833.7 & 834.9 & 836.2 & 837.9 & 839.1 & 840.8 \\
\hline Density at $15^{\circ} \mathrm{C}$ & $\mathrm{kg} / \mathrm{m}^{3}$ & 880 & 860-900 & 849 & 851 & 852 & 854 & 855 & 857 \\
\hline Acid value & $\mathrm{mg} \mathrm{KOH} / \mathrm{g}$ & 0.5 (max.) & 0.5 (max.) & 0.18 & 0.21 & 0.25 & 0.32 & 0.36 & 0.41 \\
\hline Heating value & $\mathrm{MJ} / \mathrm{kg}$ & - & - & 45.36 & 44.35 & 44.15 & 44.38 & 43.58 & 42.15 \\
\hline Copper strip corrosion & - & 3 (max.) & - & $1 a$ & $1 a$ & $1 a$ & $1 a$ & $1 a$ & $1 a$ \\
\hline
\end{tabular}

corrosion tests was measured using an analytical balance with four decimal precisions by calculating the difference in weight before and after testing. Furthermore, observations and measurements were performed every $720 \mathrm{~h}$ (30 days) of immersion for mild steel and 1,440 h (60 days) of immersion for stainless steel 316 to study the effect of immersion time on the 
rate of corrosion. The rate of corrosion of metal specimens was investigated based on data measurement by using the equation below (Fazal et al., 2012; Fazal et al., 2013):

$$
C R=\frac{8.76 \times 10^{4} \times W}{D \times A \times T}\left(\frac{\mathrm{mm}}{\text { year }}\right)
$$

Here, CR represents the corrosion rate $(\mathrm{mm} /$ year) of the chosen materials, $\mathrm{W}$ is the weight loss $(\mathrm{g}), \mathrm{D}$ is the density of the metal $\left(\mathrm{g} / \mathrm{cm}^{3}\right)$, A is the cross-sectional area of the specimen metal surface $\left(\mathrm{cm}^{2}\right)$, and $\mathrm{T}$ is the time of immersion (h).

\section{Morphology Analysis and Degraded Properties in Biodiesel}

Aside from the corrosion rate, observing the specimen surface morphology was equally important to observe changes in the specimen. The Phenom ProX Desktop SEM was used to observe the corrosion characteristic of both types of specimens. SEM analysis was performed to study the compatibility of metal or automotive materials with biodiesel-diesel fuels. Besides, an EDS is a function equipped with the above SEM device. EDS was used to obtain the compositional information on the corrosion spot. The corrosion effect of the biodiesel on mild steel and stainless steel 316 metallic materials at room temperature through metal immersion tests was investigated. The specimen was immersed in the various biodiesel concentrations, and this will cause corrosion to happen on the specimen that will affect the properties of the biodiesel. Therefore, the changes in the oil properties were measured and observed, such as kinematic viscosity, density, refractive index, and acid value. The properties measured will help to analyze the degradation of biodiesel when stored in metallic materials and estimate the degradation of biodiesel. The properties mentioned above are essential to decide the blended mixture's usability after exposure to different materials at the stated immersion period. The degradation of the physicochemical properties was discussed in detail in the Results and Discussion section.

\section{Statistical Analysis of the Material}

Statistical analysis to measure the correlation between variables on the corrosion rate was performed. The variables that were measured were the dimension of the specimen and the properties of the fuel used. The dimensions of the specimens measured were outer diameter, inner diameter, thickness, and weight before and after immersion. The fuel properties that were considered in this section were dynamic viscosity, kinematic viscosity, density at $40^{\circ} \mathrm{C}$ and $15^{\circ} \mathrm{C}$, the acid value of the fuel, and lastly, the refractive index. These variables were analyzed to investigate the factors affecting the corrosion rate of the specimen. Statistical analysis will help determine which variables have a more significant impact on the corrosion rate of the specimen. Correlation analysis and regression analysis were done in this study for the investigation.

\section{RESULTS AND DISCUSSION}

\section{Blending Ratio}

By referring to Table 4, it is noticeable that the increased concentration of W70CI30 biodiesel shows a linear change in viscosity and density of the biodiesel-diesel fuel blends. These properties are directly proportional to the percentage of biodiesel in the blend. Besides, the addition of W70CI30 biodiesel has increased the acid content in the biodiesel-diesel blend. In contrast, with an increase in the percentage of biodiesel blends, it is observed that there is a decrease in the heating value. The copper strip corrosion was performed on a biodieseldiesel blend and found that the result is 1a. The properties presented show that W70CI30 biodiesel-diesel fuel blends up to B30 are still within the limit of ASTM D6751 and EN 14214 specifications. This step will ensure that W70CI30 biodieseldiesel fuel blends are still suitable to be used in a diesel engine without modification.

\section{Corrosion Analysis}

The corrosion test is imperative to investigate before the produced fuel is used as engine fuel. Biodiesel produced is prone to be oxidized than diesel fuel, as biodiesel has fatty acid. Therefore, corrosion tests on automotive materials were performed to investigate the compatibility of the metal with biodiesel-diesel fuels. Static immersion study of biodiesel produced from blended waste cooking oil with $C$. inophyllum oil using microwave technology then blended with diesel has shown the metallic material's corrosivity. It is found that the corrosion rate tends to increase with a higher concentration of biodiesel in the fuel blends. Figures $1 \mathrm{~A}$ and $\mathbf{B}$ show the corrosion rate of mild steel and stainless steel immersed in various biodiesel-diesel blends at different times.

\section{Mild Steel}

The partial observation of mild steel at 3,600 h shows that B5-B15 have a linear increment in corrosion rate. However, B20 (1.45 $\mathrm{nm} /$ year) has a lower corrosion rate than B15 (1.65 nm/year). A more stable corrosion rate is observed as the immersion period increases. At 7,200 h, which is full observation, the corrosion rate for the biodiesel-diesel blend of B5-B30 is 0.7270, 0.9694, 1.1632, $1.2117,1.3086$, and $1.5025 \mathrm{~nm} /$ year. The corrosion rate obtained in this study is much lower than that obtained by Jin et al. (2015), who performed mild steel observation in diesel and pure palm biodiesel (B100), whose maximum corrosion rate is 0.002 and $0.038 \mathrm{~mm} /$ year, respectively, for 120 days' immersion time.

Moreover, corrosion of blended waste cooking oil with $C$. inophyllum oil is much lower than using rapeseed biodiesel-diesel blend (Hu et al., 2012). The corrosion rate of rapeseed biodiesel and diesel is $0.0182 \mathrm{~mm} /$ year and $0.0015 \mathrm{~mm} /$ year after being immersed for 60 days at $43^{\circ} \mathrm{C}$. The biodiesel produced in this study has shown relatively low corrosivity compared with other researchers' biofuel. The corrosion of mild steel can be reduced by pre-blending the biodiesel with diesel fuel to reduce the corrosivity of the mild steel. Storing biodiesel in its pure form will accelerate the corrosion. 


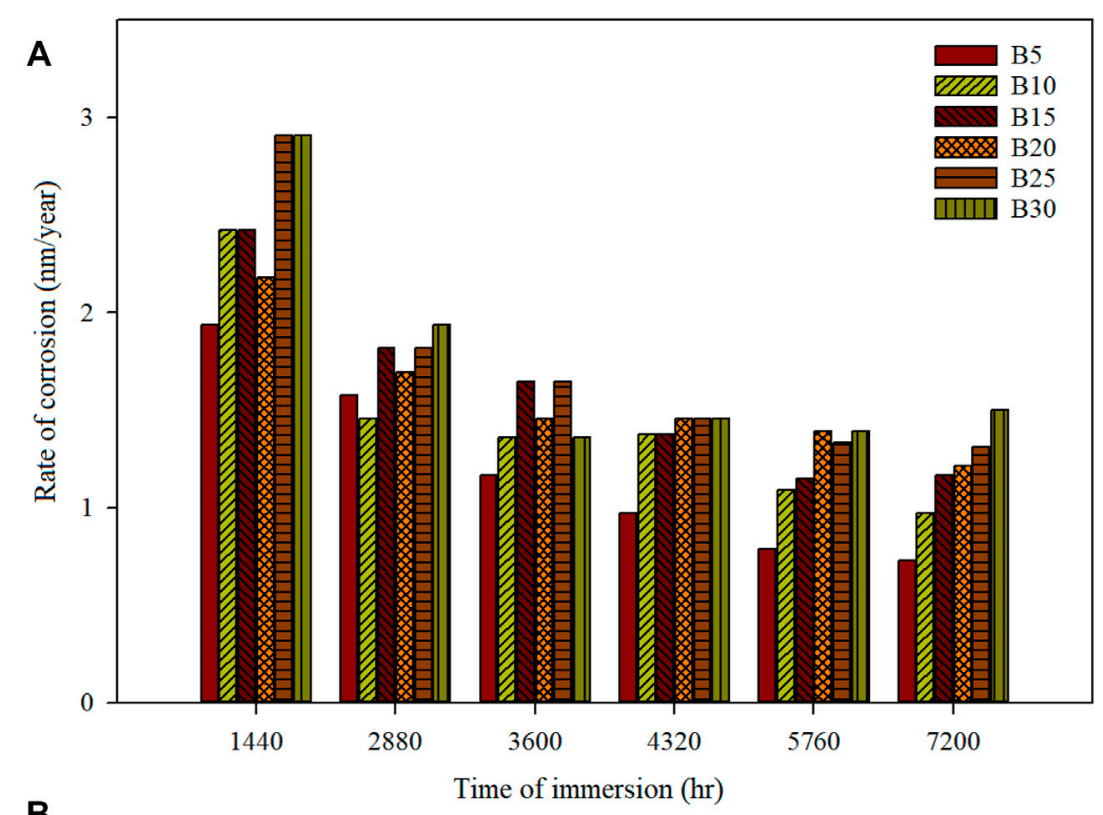

B

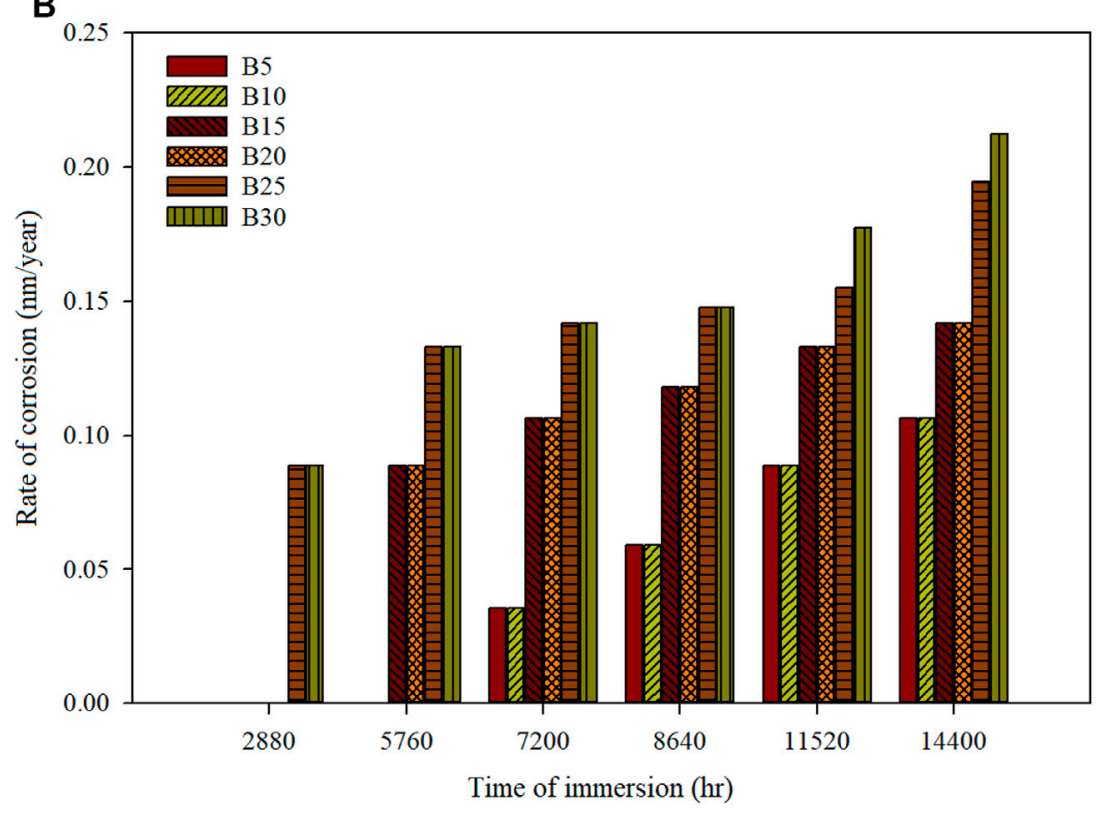

FIGURE 1 | Rate of corrosion of different biodiesel-diesel blending ratios for (A) mild steel and (B) stainless steel 316 for a specific time of immersion.

\section{Stainless Steel 316}

Stainless steel 316 has shown its high compatibility with biodiesel-diesel fuel. B5-B20 have shown no mass loss when immersed up to 2,880 h with zero corrosion rate. B25 and B30 have shown the lowest corrosion rate of $0.0890 \mathrm{~nm} /$ year at the same immersion period. At the partial observation of stainless steel 316 at 7,200 h, the corrosion rate for B5-B10, B15-B20, and $\mathrm{B} 25-\mathrm{B} 30$ is $0.0354,0.1062$, and $0.1417 \mathrm{~nm} /$ year, respectively. Whereas for the full observation at $14,400 \mathrm{~h}$, the corrosion rate for B5-B10, B15-B20, B25, and B30 was 0.1062, 0.1417, 0.1948, and $0.2125 \mathrm{~nm} /$ year, respectively. The stainless steel 316 's corrosion rate obtained after being immersed for 300 days is still much lower than that obtained by Hu et al. (2012), with a corrosion rate of $0.00087 \mathrm{~mm} /$ year after being immersed in rapeseed biodiesel for 60 days. Moreover, the corrosion rate of palm biodiesel (B100) immersed for $965 \mathrm{~h}$ is $0.000112 \mathrm{~mm} /$ year, showing a high corrosion rate compared to our study (Fasogbon and Olagoke, 2016). Stainless steel 316 has a low corrosion rate with various blended ratios of waste cooking oil with C. inophyllum oil biodiesel with diesel fuel. Exposure of stainless steel 316 with biodiesel has shown superior compatibility. Stainless steel 316 contains a high level of chromium that forms a very stable chromium oxide $\left(\mathrm{Cr}_{2} \mathrm{O}_{3}\right)$ that shows a very low corrosion rate (Dalmau et al., 2018). The corrosion of stainless steel 316 is 


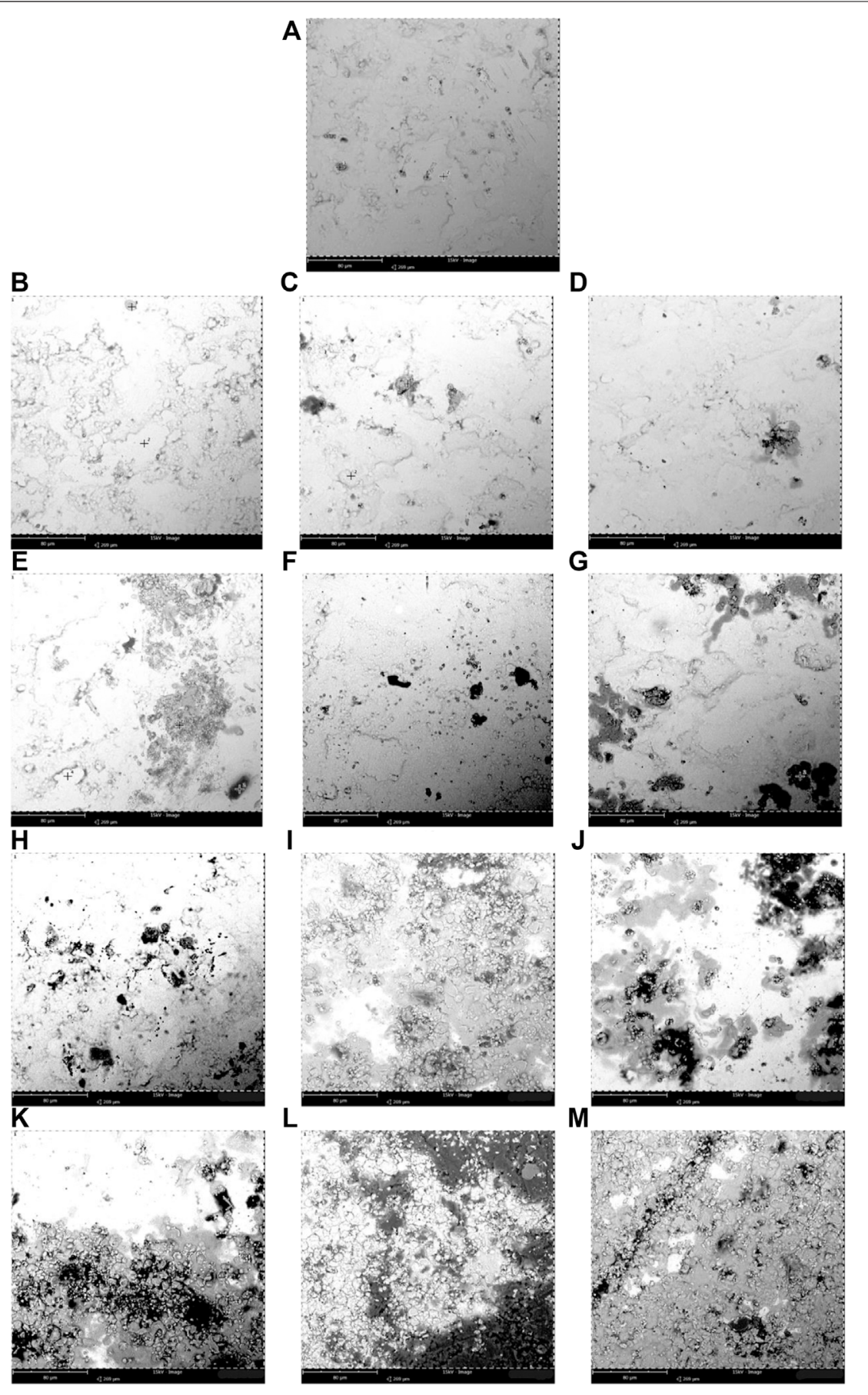

FIGURE 2 | Scanning electron microscopy (SEM) micrographs of corrosion observed at the immersed surface of the biodiesel-diesel blend mixtures with different immersion durations for mild steel (A) 0 day, (B-G) B5, B10, B15, B20, B25, and B30 at 150 days, (H-M) B5, B10, B15, B20, B25, and B30 at 300 days at room temperature $\left(25^{\circ} \mathrm{C}-30^{\circ} \mathrm{C}\right)$.

initiated with a higher concentration of biodiesel in the blending fuel and a longer immersion time.

To conclude, higher biodiesel content in the fuel blend will increase the corrosion rate of the metallic material. Similar trends were observed in other literature such as palm (Fazal et al., 2013), ghee butter (Ononiwu et al., 2015), Moringa oleifera Lam. (Fernandes et al., 2019), sunflower (Cursaru et al., 2014), Aegle marmelos Correa (Thangarasu et al., 2019), rapeseed (Hu et al., 2012), rice husk (Lu et al., 2008), Salvadora (Kaul et al., 2007), and poultry fat (Geller et al., 2008) biodiesel. The following section will discuss the surface 


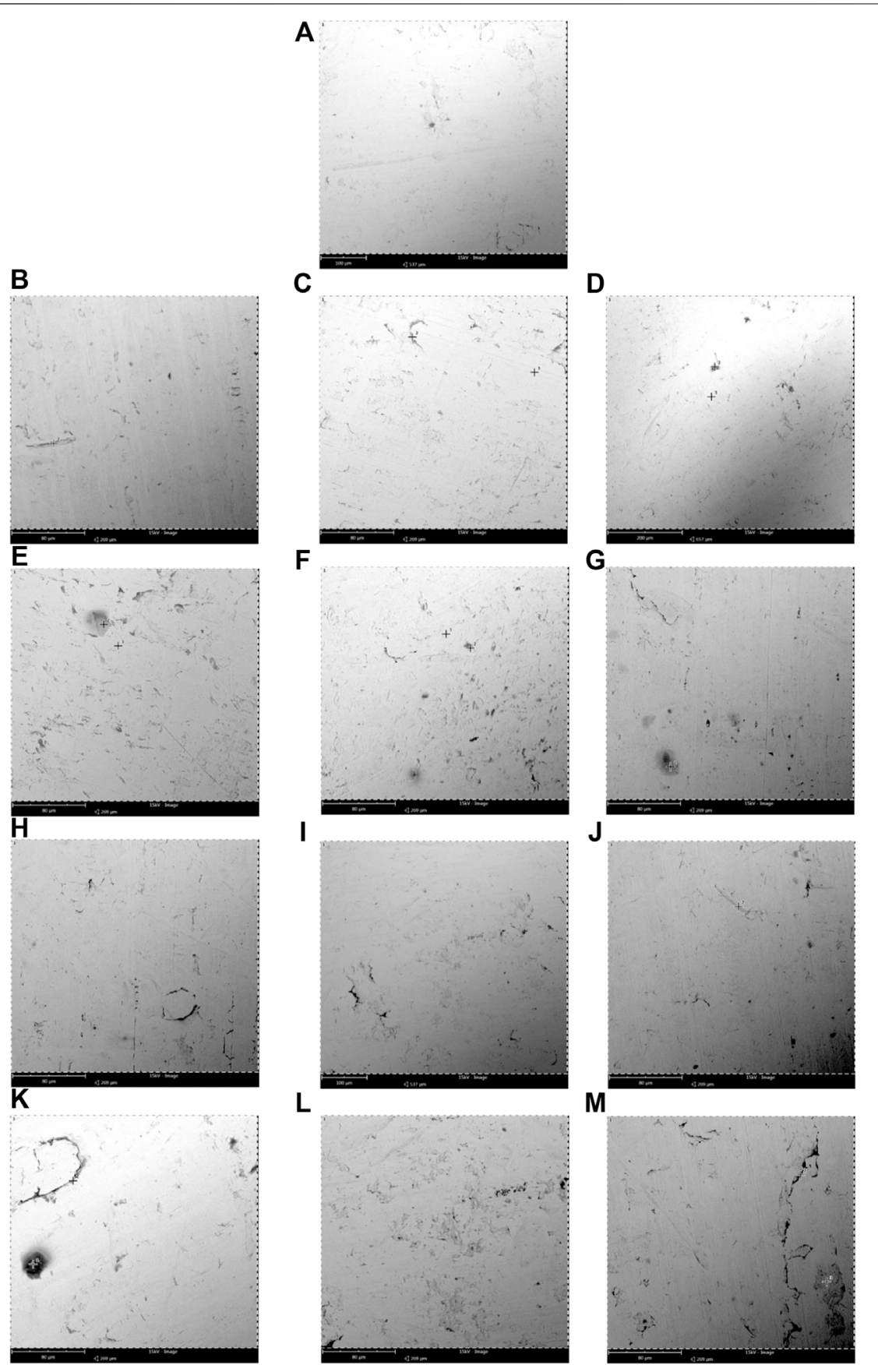

FIGURE 3 | Scanning electron microscopy (SEM) micrographs of corrosion observed at the immersed surface of the biodiesel-diesel blend mixtures with different immersion durations for stainless steel 316 (A) 0 day, (B-G) B5, B10, B15, B20, B25, and B30 at 300 days, (H-M) B5, B10, B15, B20, B25, and B30 at 600 days at room temperature $\left(25^{\circ} \mathrm{C}-30^{\circ} \mathrm{C}\right)$.

morphology of the mild steel and stainless steel 316 coupon and the corrosion mechanism of metallic materials in the biodiesel.

\section{Corrosion Characteristics of the Metal} Surface Morphology

The specimens were thoroughly cleaned before exposure for surface morphology by using SEM and EDS. The corroded surface of the immersed mild steel and stainless steel 316 specimens in the dieselbiodiesel blend fuel can be observed by referring to the SEM micrograph shown in Figures 2 and 3, respectively. The EDS composition of the mild steel and stainless steel 316 is tabulated in Table $\mathbf{5}$.

\section{Mild Steel}

Figure $2 \mathrm{~A}$ shows the mild steel specimen before immersion (0 day), Figures 2B-G show the immersion of mild steel in B5, B10, 
TABLE 5 | Electron-dispersive spectrometer (EDS) for mild steel immersed in B5-B30 at 300 days and stainless steel immersed in B5-B30 at 600 days.

\begin{tabular}{|c|c|c|c|c|c|c|c|c|}
\hline \multirow[t]{2}{*}{ Material } & \multirow{2}{*}{\multicolumn{2}{|c|}{$\begin{array}{c}\text { Time of } \\
\text { immersion }\end{array}$}} & \multirow{2}{*}{\multicolumn{2}{|c|}{ Fuel }} & \multicolumn{4}{|c|}{ Weight (\%) } \\
\hline & & & & & Iron (FE) & Oxygen & & Carbon (C) \\
\hline \multirow[t]{6}{*}{ Mild steel } & \multirow{6}{*}{\multicolumn{2}{|c|}{300 days }} & \multicolumn{2}{|c|}{ B5 } & 85.21 & \multicolumn{2}{|c|}{4.92} & 9.87 \\
\hline & & & \multicolumn{2}{|c|}{ B10 } & 80.17 & \multicolumn{2}{|c|}{6.23} & 13.6 \\
\hline & & & \multicolumn{2}{|c|}{ B15 } & 82.14 & \multicolumn{2}{|c|}{4.75} & 13.11 \\
\hline & & & \multicolumn{2}{|c|}{ B20 } & 72.28 & \multicolumn{2}{|c|}{10.53} & 17.19 \\
\hline & & & \multicolumn{2}{|c|}{ B25 } & 75.53 & \multicolumn{2}{|c|}{13.42} & 11.05 \\
\hline & & & \multicolumn{2}{|c|}{$\mathrm{B} 30$} & 77.6 & \multicolumn{2}{|c|}{14.36} & 8.04 \\
\hline \multirow[t]{2}{*}{ Material } & \multirow{2}{*}{$\begin{array}{c}\text { Time of } \\
\text { immersion }\end{array}$} & \multirow[t]{2}{*}{ Fuel } & \multicolumn{6}{|c|}{ Weight (\%) } \\
\hline & & & Iron (FE) & Oxygen (O) & Carbon (C) & Chromium (Cr) & Nickel (Ni) & Silicon (Si) \\
\hline \multirow[t]{6}{*}{ Stainless steel } & 600 days & B5 & 58.08 & 7.29 & 19.21 & 8.99 & 3.82 & 2.61 \\
\hline & & B10 & 55.34 & 7.89 & 19.55 & 9.03 & 3.44 & 4.75 \\
\hline & & B15 & 52.45 & 9.9 & 20.56 & 8.59 & 3.99 & 4.51 \\
\hline & & B20 & 50.85 & 9.59 & 22.22 & 8.14 & 3.08 & 6.12 \\
\hline & & B25 & 56.11 & 6.44 & 23.78 & 7.22 & 3.78 & 2.67 \\
\hline & & B30 & 52.45 & 7.9 & 24.56 & 8.59 & 3.99 & 2.51 \\
\hline
\end{tabular}

B15, B20, B25, and B30 at 3,600 h, and Figures $2 \mathbf{H}-\mathbf{M}$ show the immersion of mild steel in B5, B10, B15, B20, B25, and B30 at $7,200 \mathrm{~h}$. The oxidation process initiates the pitting formed on mild steel as the biodiesel contains acid compounds. This pitting is triggered by the metal ions released from the metallic surface that will later alter the biodiesel's fuel properties and oxidation stability (Hu et al., 2012; Alves et al., 2019).

The corrosion on the mild steel is intense with a higher blending ratio (B30) compared to the lowest, as can be seen in Figures $2 \mathrm{G}$ and $\mathbf{M}$ for 3,600 $\mathrm{h}$ and 7,200 h, respectively, of the immersion period. The specimen immersed in B5 for 3,600 h (Figure 2B) shows a lower corroded spot, but it shows a relatively more corroded spot when the mild steel specimen is immersed for a more extended period $(7,200 \mathrm{~h})$, as shown in Figure $\mathbf{2 H}$. There is pit formation (dark spot) in the immersed mild steel specimens with a blending ratio of B10-B30 for 3,600 h (Figures 2C-G). Therefore, as the immersion period increases, the corrosion is more intense, resulting in more pit formation and corrosion effect scatter around the mild steel specimens, as shown in Figures 2H-M. The weight percentage of the oxygen atom shown in Table 5 indicated the oxides formed on the specimen. Higher biodiesel concentration in the blending fuel showed more pits with various sizes (Figures 2A-G). After 7,200 h of immersion, more cavities and black spots were found on the mild steel's surface, especially Figures $2 \mathrm{~L}$ and $\mathbf{M}$. B30 showed higher iron [77.6 (w/w)\%], oxygen [14.36 (w/w)\%], and carbon [8.04 (w/ w)\%] atom contents. EDS chemical characterization results indicate the presence of a metal oxide film on the specimen. The pit formation and black spots found on the coupons are due to oxidation. Biodiesel with highly unsaturated fatty acid content will cause higher reactivity with oxygen molecules. These molecules form active oxygen atoms that transform the metal oxides into other metal compounds by further oxidation. Metal oxides formed on the surfaces are commonly $\mathrm{Fe}(\mathrm{OH})_{3}$, $(\mathrm{FeO})_{2} \mathrm{CO}_{3}$, and $\mathrm{Fe}_{2} \mathrm{O}_{3}$, also reported by Fazal et al. (2017). The mechanism of corrosion in mild steel is described in Eq. (1)-Eq. (3).
Spontaneous oxidation of iron to iron (III) oxides:

$$
4 \mathrm{Fe}(s)+3 \mathrm{O}_{2}(g) \rightarrow 2 \mathrm{Fe}_{2} \mathrm{O}_{3}(s)
$$

The presence of oxygen molecules and water with iron (II) hydroxide will cause a substitution reaction to form iron (III) oxide-hydroxide.

$$
4 \mathrm{Fe}(\mathrm{OH})_{2}(s)+\mathrm{O}_{2}(g)+2 \mathrm{H}_{2} \mathrm{O}(l) \rightarrow 4 \mathrm{Fe}(\mathrm{OH})_{3}(s)
$$

The presence of carbon dioxide and water molecules form $\mathrm{H}_{2} \mathrm{CO}_{3}$, then react with iron (III) hydroxide to form iron (II) oxide-carbonate

$$
4 \mathrm{H}_{2} \mathrm{CO}_{3}(l)+\mathrm{FeO}(\mathrm{OH})(s) \rightarrow 4(\mathrm{FeO})_{2} \mathrm{CO}_{3}(s)
$$

Corrosion occurs more intensively in mild steel surrounded with a higher concentration of biodiesel blend. The chemical reaction produces oxygenated compounds due to active oxygen atoms, water, and other volatile compounds present in biodiesel blends that eventually corrode the mild steel. The small pits formation (micropits) will create a "protective layer" on the mild steel and decrease the corrosion rate. Biodiesel is more corrosive than diesel fuel (Ononiwu et al., 2015). High water content and higher acidity of biodiesel will increase the corrosive activity. Even high-quality biodiesel with prolonged exposure to mild steel will affect the metallic surface and piston parts (Cestari et al., 2021).

\section{Stainless Steel 316}

Figure 3A shows the stainless steel 316 specimen before immersion (0 days), Figures $\mathbf{3 B}-\mathbf{G}$ show the immersion of stainless steel 316 in B5, B10, B15, B20, B25, and B30 at 300 days $(7,200 \mathrm{~h})$, and Figures $\mathbf{3 H}-\mathbf{M}$ show the immersion of stainless steel 316 in B5, B10, B15, B20, B25, and B30 at 600 days (14,400 h). Exposure of stainless steel coupons in B5 and $\mathrm{B} 10$ for $7,200 \mathrm{~h}$ shows less mass loss and a low corrosion rate. The SEM micrograph showed that slight corrosion spots were illustrated in B5 and B10. Little corrosion pits are seen in the 
SEM morphology for B15 and B20. More pits were found in B25 and B30 blending fuels. The corrosion rate for 7,200 h of all blending fuel is minimal. The SEM morphology has successfully captured pit formation in the coupons. The result has shown that higher biodiesel composition in blended fuel will stimulate corrosion on the stainless steel 316 coupon at the same immersion period.

The morphology obtained from SEM presented in Figures 3H-M shows that stainless steel 316 has higher corrosion resistance when the specimens are immersed in various biodiesel-diesel fuel ratios. Even though the immersion periods were extended beyond the immersion period of the mild steel specimens, the corrosion attack is still minor with little sediment formation. The EDS results indicate that the presence of carbon, oxygen, and chromium content for B20 at $600 \mathrm{~h}$ is $22.22(\mathrm{w} / \mathrm{w}) \%$, $9.59(\mathrm{w} / \mathrm{w}) \%$, and $8.14(\mathrm{w} / \mathrm{w}) \%$ (Table 5). Stainless steel 316 exposure to biodiesel-diesel blend causes titanium carbides (TiC) and chromium (III) oxide $\left(\mathrm{Cr}_{2} \mathrm{O}_{3}\right)$ to form on the specimen. $\mathrm{TiC}$ particles formed a carbide stabilizer that reinforced the stainless steel 316 surfaces, while $\mathrm{Cr}_{2} \mathrm{O}_{3}$ forms a thin layer of oxides on the stainless steel surface, called the "passive layer." Stainless steel exposed to oxygen molecules caused the formation of metal oxide films that prevented the metal's oxidation and resulted in a lower corrosion rate, as also reported by Kugelmeier et al. (2021). Passive film is thin and not visible, and the metal remains lustrous and smooth with the film attached to it. The passive film will reform when the surface is scratched, and it prevents the corrosion from spreading into the metal's internal structure. Stainless steel can prevent metallic contamination to the biodiesel-diesel blend due to the passive character of the film. The alloy can make storage tanks or tankers to transport biodiesel due to its corrosion resistance. It is also recommended to be used to make some common parts in the engine such as exhaust manifold, fuel pump, fuel filter, fuel lines, fuel tank, and even fastener, retainers, clips, screws, nuts, and bolts that can be used to secure the engine parts. The mentioned parts are consciously exposed to biodiesel-diesel, so it is vital to choose a suitable material to secure the engine compartment and routing lines and for detailing the engine.

Besides, biodiesel in this study was produced from non-edible oil (waste cooking oil blend with $C$. inophyllum oil) with a high unsaturated fatty acid content. In fact, high unsaturated fatty acid contents will cause high reactivity with an oxygen molecule. It will cause low oxidation stability of the biodiesel. According to ASTM D6751 and EN 14214 standards, the oxidation stability at $110^{\circ} \mathrm{C}$ should be at $3-6 \mathrm{~h}$, respectively. The W70CI30 biodiesel has significantly higher oxidation stability $(18.03 \mathrm{~h})$. The superior oxidation stability has slowed down the corrosion rate of the metallic materials. The metallic materials were immersed in a surrounding with low active oxygen atoms that will create a less favorable environment for corrosion attack. The corrosion rate and morphology of mild steel and stainless steel have shown that the corrosion attack was milder than other studies (Jin et al., 2015; Cestari et al., 2021; Kugelmeier et al., 2021). The following section will discuss the behavior of the degraded biodiesel in terms of changes in fuel properties after each immersion period of the metal materials of various blending ratios of W70CI30 biodiesel-diesel.

\section{The Behavior of Degraded Biodiesel}

As the specimen is immersed in the various biodiesel-diesel blends, corrosion occurs, and this causes the degradation of the properties of the blended mixture. The degradation of the physicochemical properties was observed, such as viscosity, density, reflective index, and acid value and was discussed. The properties mentioned above are essential to decide the blended mixture's usability after exposure to different materials at the stated immersion period.

\section{Kinematic Viscosity}

Exposure of biodiesel-diesel blend with the metallic materials causes degradation of the fuel mixture. Viscosity represents the fluidity of the blended mixture; the viscosity changes will influence the combustion of the fuel mixture. High viscosity in the blended mixture will cause a burden to the fuel pump, which would result in more energy for the fuel pump to deliver the fuel to the injector. High-viscosity scenario will eventually reduce the engine's power as it requires more input energy (Nautiyal et al., 2020). Besides, higher viscosity will cause larger droplets when fuel exits the injector. Large droplets will cause sudden temperature changes at the surface of the cylinder that induces incomplete combustion. The incomplete combustion will increase the chamber's deposit and produce pungent gases forming aldehydes and acids (Malpass and Motheo, 2003).

The fuel kinematic viscosity should be within a range of $1.90-6 \mathrm{~mm}^{2} / \mathrm{s}$ and $3.5-5 \mathrm{~mm}^{2} / \mathrm{s}$ according to the ASTM D6751 and EN 14214 standards, respectively. The kinematic viscosity of WC70CI30 biodiesel-diesel blend mixture before and after immersion of mild steel and stainless steel 316 is shown in Figures $\mathbf{4 A}$ and $\mathbf{B}$, respectively. The kinematic viscosity of the biodiesel-diesel blend increases as the concentration of the biodiesel increases in the blended mixture in all the cases. Besides, the kinematic viscosity increases with the time of immersion of mild steel and stainless steel 316 in the blended mixture. The kinematic viscosity for mild steel with an immersion period of 7,200 h for biodiesel-diesel blends of B5, B10, B15, B20, B25, and B30 is $3.2348,3.3349,3.4043,3.4925,3.5213$, and $3.6267 \mathrm{~mm}^{2} / \mathrm{s}$, respectively. The degradation of fuel in kinematic viscosity after being exposed for $7,200 \mathrm{~h}$ in various blending ratios is less than $9 \%$ compared with the fuels' initial conditions. The kinematic viscosity for stainless steel with an immersion period of $14,400 \mathrm{~h}$ for biodiesel-diesel blends of B5, B10, $\mathrm{B} 15, \mathrm{~B} 20, \mathrm{~B} 25$, and $\mathrm{B} 30$ is $3.5123,3.5032,3.6959,3.8023$, 3.8121 , and $3.9245 \mathrm{~mm}^{2} / \mathrm{s}$, respectively. The degradation of fuel in kinematic viscosity after being exposed for $14,400 \mathrm{~h}$ in various blending ratios is less than $16 \%$ compared with the fuels' initial conditions. The kinematic viscosity of all blended fuel fulfills the specification given by ASTM D6751, but B5-B20 did not meet the requirement by EN 14214 standards. B5-B20 do not degrade as fast as other blended fuels. The kinematic viscosity shows a similar trend for both mild steel and stainless steel material, with similar degradation percentages of the fuels based on time of immersion. 

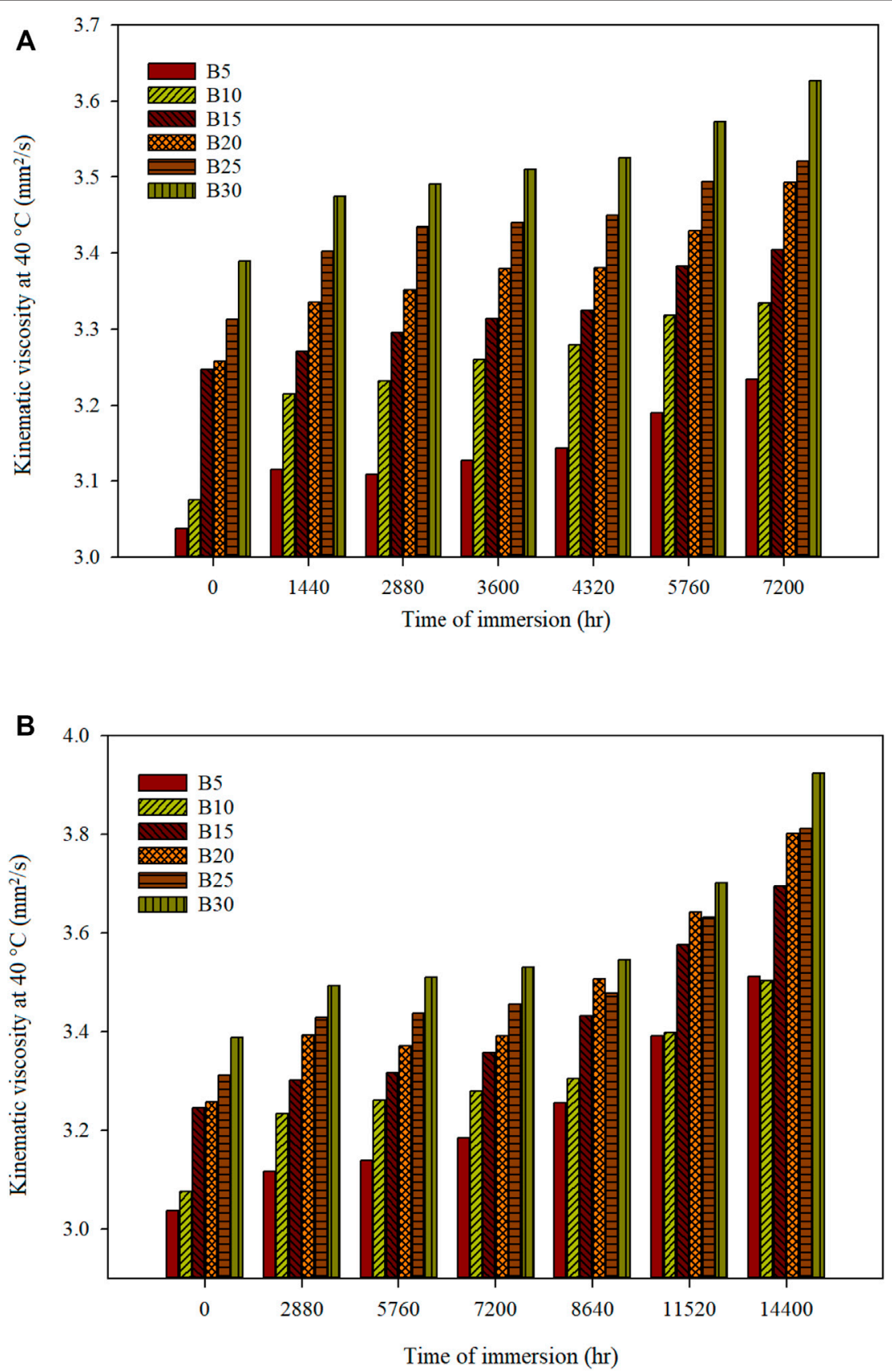

FIGURE 4 | Kinematic viscosity at $40^{\circ} \mathrm{C}$ of different biodiesel-diesel blending ratios for (A) mild steel and (B) stainless steel 316 for a specific time of immersion.

\section{Density}

According to the ASTM D6751 and EN 14214 standards, the fuel density should be lower than 880 and between a range of $860-900 \mathrm{~kg} /$ $\mathrm{m}^{3}$, respectively. The density of W70CI30 is $861.8 \mathrm{~kg} / \mathrm{m}^{3}$, which is well within the range specified in both standards. The density of W70CI30 is slightly higher than those for diesel $\left(841.1 \mathrm{~kg} / \mathrm{m}^{3}\right)$, palm $(858.9 \mathrm{~kg} /$ $\mathrm{m}^{3}$ ), and Moringa $\left(859.6 \mathrm{~kg} / \mathrm{m}^{3}\right.$ ) biodiesel (Rashed et al., 2016). However, the density of W70CI30 is significantly lower than obtained by Dubey and Gupta (2017) (Jatropha biodiesel, $881 \mathrm{~kg} /$ $\mathrm{m}^{3}$ ) and Xue et al. (2016) (WCO biodiesel, $887.6 \mathrm{~kg} / \mathrm{m}^{3}$ ). Variation of density is attributed to the difference of feedstock, quality of feedstocks, biodiesel production procedure, and the equipment used for biodiesel production (heating mantle, ultrasonic, supercritical method). The blending of biodiesel with diesel fuel will reduce the density of the blended fuel. Therefore, density is an equally important property, as it will also affect the efficiency of fuel atomization and combustion characteristics. The density will affect the fuel mass that reaches the combustion chamber, and then it will influence the air/fuel ratio and engine performance (Shekofteh et al., 2020). 

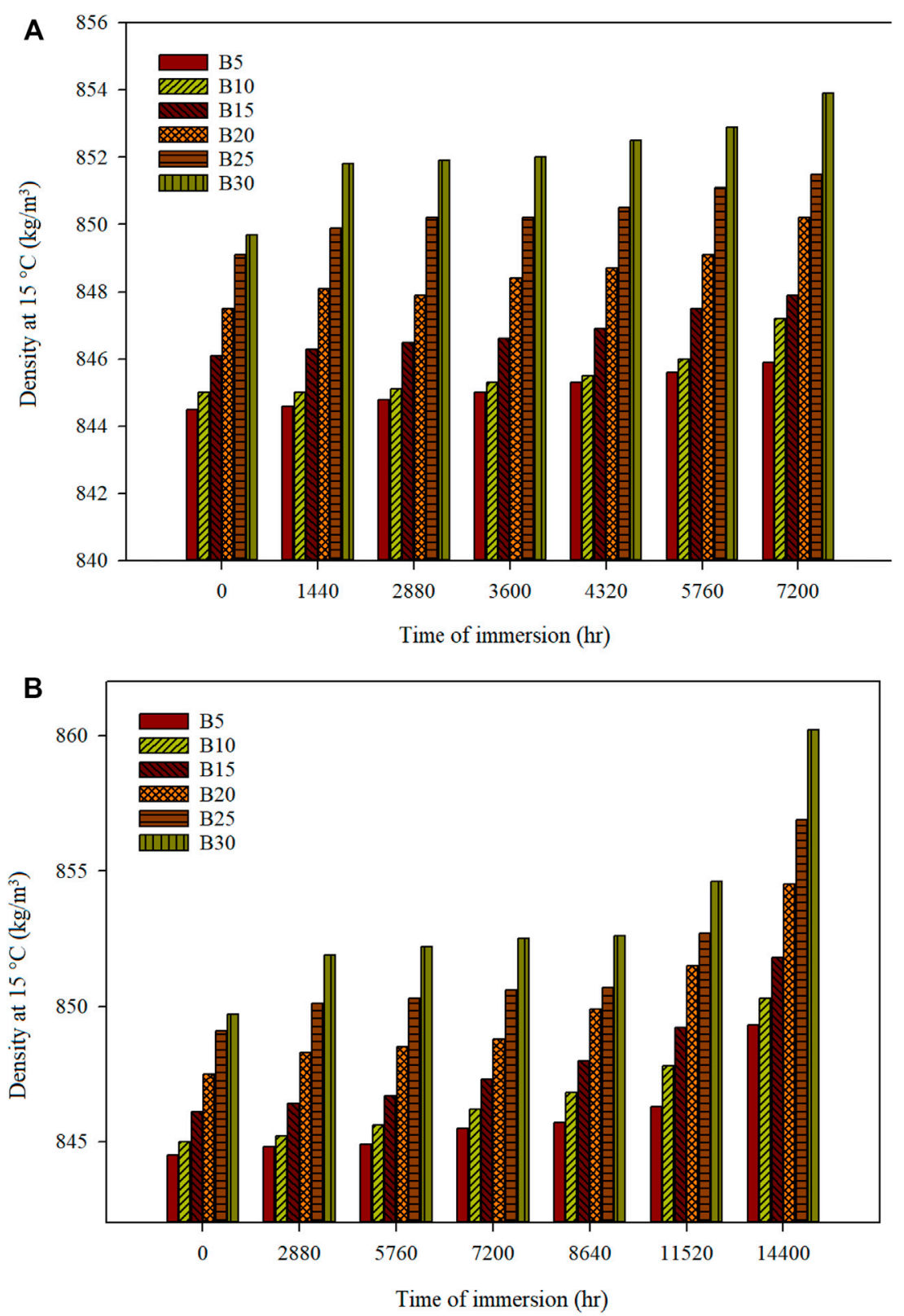

FIGURE 5 | Density at $15^{\circ} \mathrm{C}$ of different biodiesel-diesel blending ratios for (A) mild steel and (B) stainless steel 316 for a specific time of immersion.

The density for the mild steel and stainless steel 316 specimen immersed in the biodiesel-diesel fuel mixture is presented in Figure 5. The density of mild steel with an immersion period of 7,200 h of biodiesel-diesel blends of B5, B10, B15, B20, B25, and $\mathrm{B} 30$ is $845.9,847.2,847.9,850.2,851.5$, and $853.9 \mathrm{~kg} / \mathrm{m}^{3}$, respectively. The degradation in the density of all tested fuels at $7,200 \mathrm{~h}$ is less than $0.5 \%$ compared with the fuel's initial density. The density of stainless steel with an immersion period of $14,400 \mathrm{~h}$ for biodiesel-diesel blends of B5, B10, B15, B20, B25, and $\mathrm{B} 30$ is $849.3,850.3,851.8,854.5,856.9$, and $860.2 \mathrm{~kg} / \mathrm{m}^{3}$, respectively, with degradation less than $1.3 \%$ compared with the fuel's initial density. However, the density of B5-B30 (mild steel) after being immersed for 7,200 $\mathrm{h}$ is significantly lower than that stated in EN 14214. The density of B5-B25 (stainless steel 316) after being immersed for $14,400 \mathrm{~h}$ is also below the requirement stipulated in the EN 14214. However, density values of both metallic materials immersed in various biodiesel-diesel blends fulfill the ASTM D6751. The degradation of density is dependent on the FAME composition, molar mass, and water content. As observed, the changes in the density values are influenced by the metallic material and the time of immersion. 

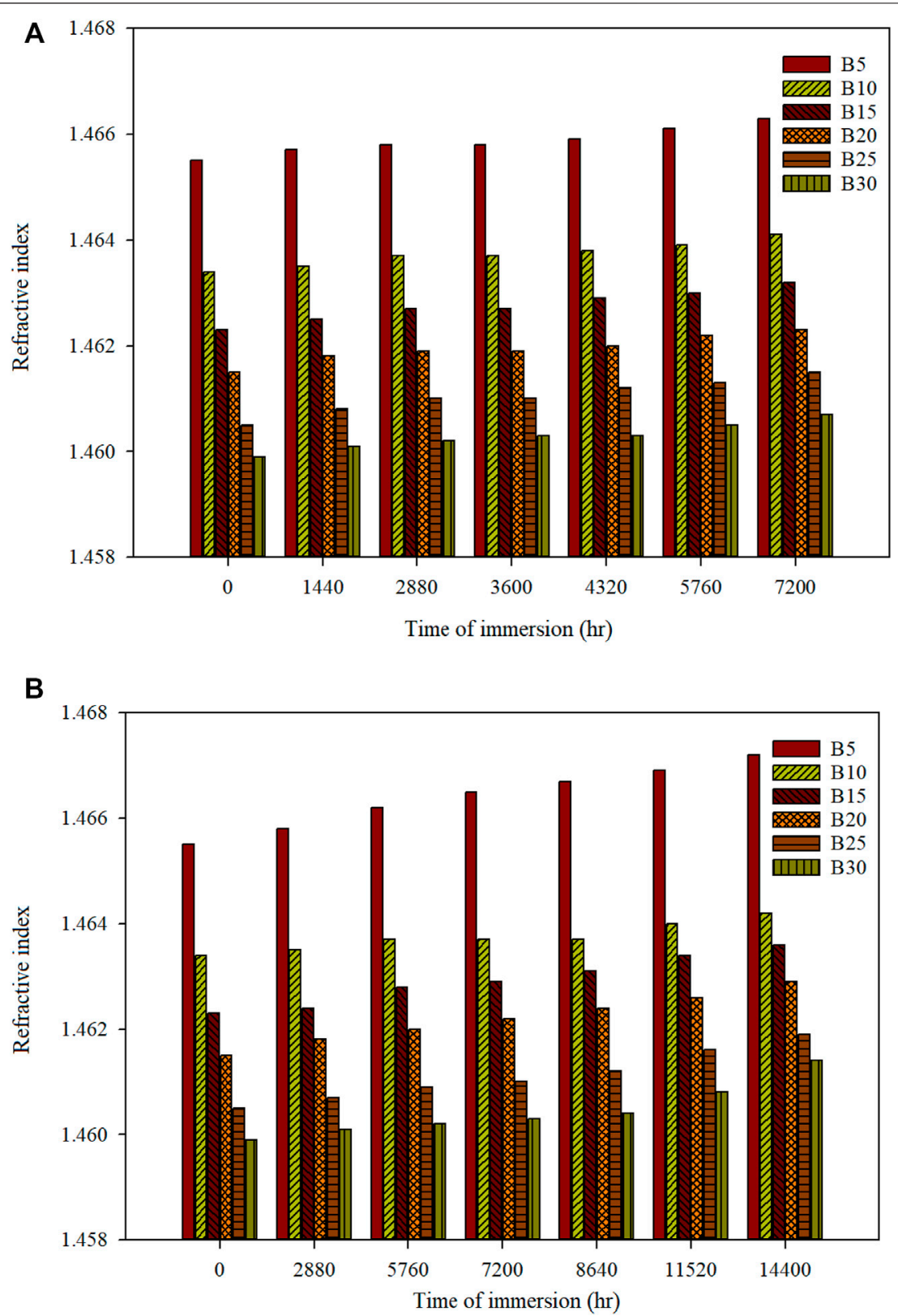

FIGURE 6 | Refractive index of different biodiesel-diesel blending ratios for (A) mild steel and (B) stainless steel 316 for a specific time of immersion.

\section{Refractive Index}

A refractive index is a dimensionless number used to indicate light propagation through the medium. The refractive index measures how much the path of light is refracted when it passes through a material. The refractive index can precisely measure the degradability of the fuel instead. It is more accurate than observing the color changes on the biodiesel-diesel blends before and after the test. The mild steel and stainless steel 316 show no color changes after their full observation period, both exhibiting light yellow tones. However, no color changes reflect the excellent compatibility between the metallic materials and the biodiesel-diesel blended fuels. By referring to the changes in the refractive index shown in Figure 6, it can be observed that increasing the concentration of the biodiesel content in the blending ratio will reduce the refractive index of the medium. The refractive index of mild steel with an immersion period of 7,200 h of biodiesel-diesel blends of B5, B10, B15, B20, B25, and $\mathrm{B} 30$ is $1.4663,1.4641,1.4632,1.4623,1.4615$, and 1.4607, respectively. For the stainless steel, the refractive index with an immersion period of $14,400 \mathrm{~h}$ of biodiesel-diesel blends of $\mathrm{B} 5$, $\mathrm{B} 10, \mathrm{~B} 15, \mathrm{~B} 20, \mathrm{~B} 25$, and $\mathrm{B} 30$ is $1.4663,1.4641,1.4632,1.4623$, 1.4615 , and 1.4607 , respectively. The degradation based on the refractive index is less than $0.1 \%$ compared with the initial's refractive index. Degradation has shown a steady increment in 

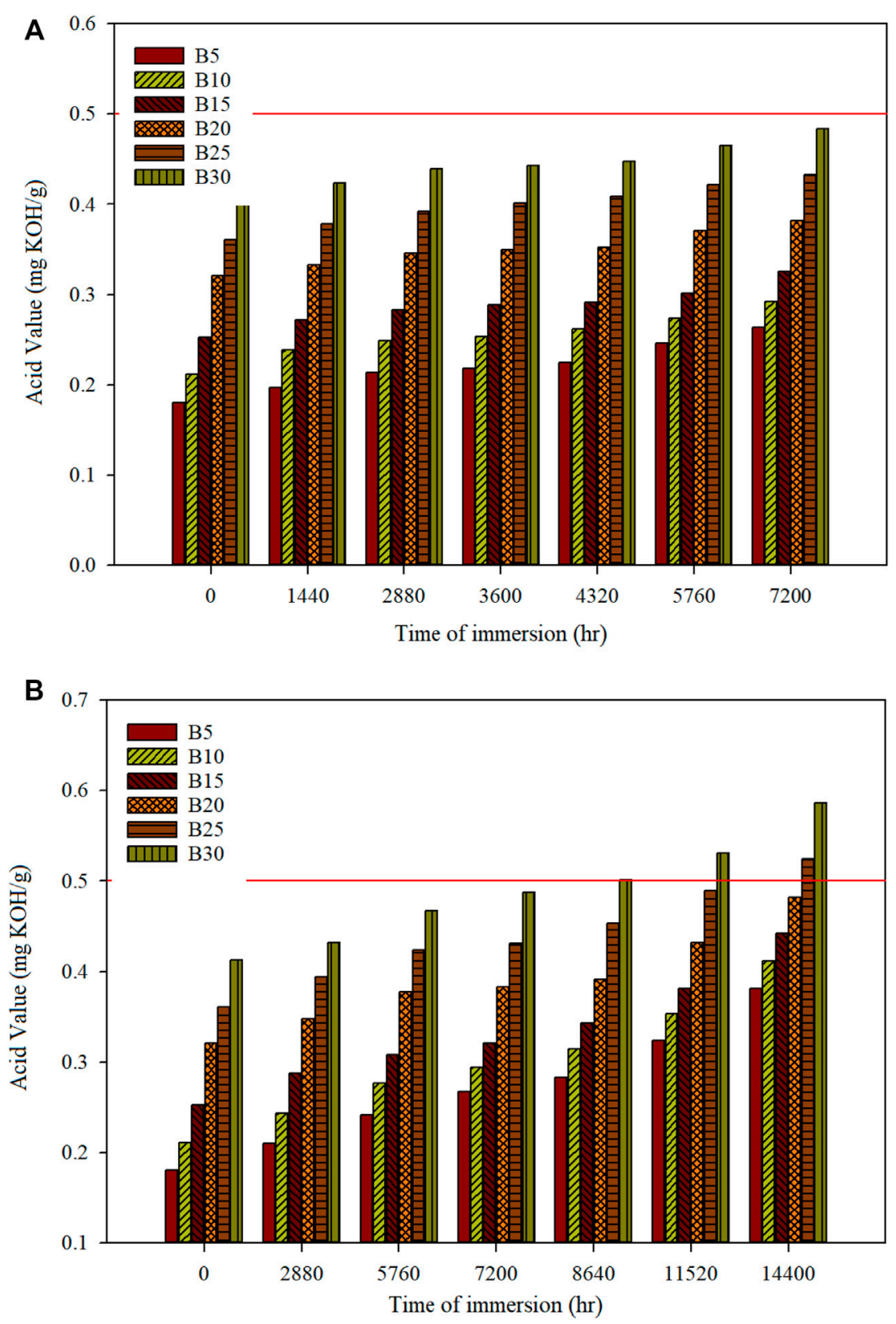

FIGURE 7 | Acid value of different biodiesel-diesel blending ratios for (A) mild steel and (B) stainless steel 316 for a specific time of immersion.

refractive index for all blended fuels. Hence, the refractive index can be considered another property to measure the degradation of the fuel. The degradation of the fuel is generally measured by referring to the changes in density, kinematic viscosity, and acid value.

\section{Acid Value}

Generally, the acid value determination is used to quantify acid content by adding a certain amount of potassium hydroxide to neutralize acidity in the oil sample. The limit of acid value in the biodiesel blend is $0.5 \mathrm{mg} \mathrm{KOH} / \mathrm{g}$ for both ASTM D6751 and EN
14214 standards. The acid value of W70CI30 biodiesel is $0.46 \mathrm{mg}$ $\mathrm{KOH} / \mathrm{g}$, which met the limit stipulated in both standards. The significantly high acid value of W70CI30 biodiesel is due to crude C. inophyllum oil, which consists of more FFA. The W70CI30 acid value is significantly higher than those for diesel $(0.0017 \mathrm{mg}$ $\mathrm{KOH} / \mathrm{g}$ ), C. inophyllum (0.41 mg KOH/g) (Ong et al., 2019), and waste cooking $(0.37 \mathrm{mg} \mathrm{KOH} / \mathrm{g}$ ) (Xue et al., 2016) biodiesel. Blending with diesel has reduced the overall acid value of the blended fuels. The acid value for the biodiesel-diesel fuel mixture before and after immersion of both metal specimens is shown in Figure 7. The acid value of mild steel with an immersion period of 
TABLE 6 | Descriptive statistics for mild steel and stainless steel 316.

\begin{tabular}{|c|c|c|c|c|c|c|}
\hline \multirow[t]{2}{*}{ Variable } & \multicolumn{2}{|c|}{ Mild steel } & \multicolumn{4}{|c|}{ Stainless steel 316} \\
\hline & Mean & Std. Deviation & $\mathbf{N}$ & Mean & Std. Deviation & $\mathbf{N}$ \\
\hline Corrosion rate ( $\mu \mathrm{m} /$ year) & 1.1640 & 0.40325 & 60 & 0.0957 & 0.06523 & 60 \\
\hline Days of immersion & 165 & 88.896 & 60 & 330 & 173.791 & 60 \\
\hline Weight before immersion (g) & 1.7991 & 0.04309 & 60 & 1.6743 & 0.02146 & 60 \\
\hline Weight after immersion (g) & 1.7976 & 0.04306 & 60 & 1.5739 & 0.02145 & 60 \\
\hline Weight difference (mg) & 1.5768 & 0.64476 & 60 & 0.3550 & 0.31214 & 60 \\
\hline Outer diameter (mm) & 17.9177 & 0.31763 & 60 & 17.5975 & 0.29974 & 60 \\
\hline Inner diameter (mm) & 8.1827 & 0.08626 & 60 & 8.6572 & 0.02964 & 60 \\
\hline Thickness (mm) & 1.2695 & 0.07749 & 60 & 8.6572 & 0.02964 & 60 \\
\hline Dynamic Viscosity at $40^{\circ} \mathrm{C}$ & 2.7914 & 0.1181 & 60 & 2.8779 & 0.1703 & 60 \\
\hline Kinematic viscosity at $40^{\circ} \mathrm{C}$ & 3.3502 & 0.1327 & 60 & 3.4547 & 0.1882 & 60 \\
\hline Density at $40^{\circ} \mathrm{C}$ & 831.232 & 2.7076 & 60 & 832.465 & 3.4287 & 60 \\
\hline Density at $15^{\circ} \mathrm{C}$ & 848.225 & 2.7160 & 60 & 849.465 & 3.4287 & 60 \\
\hline Acid value & 0.3301 & 0.0823 & 60 & 0.3792 & 0.0931 & 60 \\
\hline Refractive index & 1.4626 & 0.0018 & 60 & 1.4629 & 0.0020 & 60 \\
\hline
\end{tabular}

7,200 $\mathrm{h}$ for biodiesel-diesel blends of B5, B10, B15, B20, B25, and $\mathrm{B} 30$ is $0.2635,0.2922,0.3259,0.3815,0.4326$, and $0.4835 \mathrm{mg}$ $\mathrm{KOH} / \mathrm{g}$, respectively. The acid value of mild steel with an immersion period of $7,200 \mathrm{~h}$ is still within the stipulated limit set by the ASTM D6751 and EN 14214 standards. The acid value of stainless steel with an immersion period of $14,400 \mathrm{~h}$ for biodiesel-diesel blends of B5, B10, B15, B20, B25, and B30 is $0.3815,0.4120,0.4423,0.4823,0.5247$, and $0.5867 \mathrm{mg} \mathrm{KOH} / \mathrm{g}$, respectively. However, the acid value for stainless steel 316 immersions of $\mathrm{B} 30$ is $0.5013 \mathrm{mg} \mathrm{KOH} / \mathrm{g}$ at an immersion period of $8,640 \mathrm{~h}$ and is at the border of the limits. It can be observed that the acid value has increased when the time of immersion is extended beyond the limit. When the immersion time reaches $12,960 \mathrm{~h}$, the acid value for both B25 and B30 is 0.5123 and $0.5548 \mathrm{mg} \mathrm{KOH} / \mathrm{g}$, respectively, exceeding the limits of $0.5 \mathrm{mg} \mathrm{KOH} / \mathrm{g}$. The acid value of the other blending ratios will take turns to exceed the limits of ASTM D6751 and EN14214 standards when the immersion time has exceeded 14,400 h. The acid value in this study is significantly lower than that obtained by Jin et al. (2015) [palm biodiesel, $2.2 \mathrm{mg} \mathrm{KOH/g} \mathrm{(120} \mathrm{days)].} \mathrm{Diesel}$ fuel is more stable than palm biodiesel in terms of acid value. Hence, in this study, the blending of biodiesel with diesel fuels has reduced the drastic changes of acidity that will commonly happen to pure biodiesel. The changes in the acid value of the blending fuel represent the degradation trends of the metallic materials due to the oxidation of FAME. The increase in the content of FFAs will cause issues on the usability of the fuel in the engine system, especially at the engine fuel system, and it will cause fuel filter clogging (Monirul et al., 2015; Alves et al., 2019).

\section{Statistical Analysis on the Factors Affecting the Corrosion Behavior on the Mild Steel and Stainless Steel 316 Descriptive and Correlation Analysis}

Descriptive statistics describe the basic features of the data in this study and provide summaries about the data measured. The data in this study consist of a total of 120 cases collected from the corrosion behavior analysis. Table 6 described the descriptive statistics of this study for the mild steel and stainless steel 316 . Correlation analysis was needed to verify and understand the relationship between corrosion rate and the investigated variables. The coefficient of correlation will measure the strength and direction of a linear relationship between two numerical variables. There are three types of correlation, which are neutral, negative, and positive correlation. The correlation values close to 0 indicate weak correlation (neutral correlation), whereas the negative values indicate an inverse relationship, and positive values indicate a direct relationship. The value of the variable must lie between -1 and 1 ; the minimum amount of 0.5 correlation is needed to judge the strong strength of the correlation variables with the corrosion rate. The Pearson correlation with two-tailed test significance was performed for the study of the variables in this part. The null and alternative hypotheses are shown below:

$\mathrm{H}_{0}$ : Variable is not significantly affected by corrosion rate.

$\mathrm{H}_{1}$ : Variable is significantly affected by corrosion rate.

By referring to Table 7, the Pearson correlation and covariance between corrosion rate and variables for both mild steel and stainless steel 316 are shown. In order to reject the null hypothesis in favor of the alternate hypothesis, the p-value of the model should be less than 0.05 or 0.01 , which is the significance level chosen in this study. The Pearson correlation for mild steel is significant at 0.01 for the day of immersion, blending ratio, weight difference, outer diameter, and refractive index. While other variables that are significant at 0.05 are density at $40^{\circ} \mathrm{C}$ and $15^{\circ} \mathrm{C}$ and acid value. Since the p-value is less than 0.05 , there is sufficient evidence to reject the null hypothesis in favor of the alternative hypothesis. Hence, the mentioned variables significantly affect the corrosion rate of the mild steel. For stainless steel 316 , the variables that significantly affect the corrosion rate are the day of immersion, blending ratio, weight difference, outer diameter, inner diameter, dynamic viscosity, kinematic viscosity, density, acid value, and refractive index. The $\mathrm{p}$-value of the aforementioned variables is less than 0.01 , which gives great reason to reject the null hypothesis. 
TABLE 7 | Pearson correlation and covariance between corrosion rate with variables.

\begin{tabular}{|c|c|c|c|c|c|c|c|}
\hline & $\begin{array}{l}\text { Corrosion } \\
\text { rate }\end{array}$ & $\begin{array}{c}\text { Day of } \\
\text { immersion }\end{array}$ & $\begin{array}{l}\text { Blending } \\
\text { ratio }\end{array}$ & $\begin{array}{c}\text { Weight } \\
\text { difference }(\mathbf{m g})\end{array}$ & $\begin{array}{c}\text { Outer } \\
\text { diameter }\end{array}$ & $\begin{array}{l}\text { Inner } \\
\text { diameter }\end{array}$ & Thickness \\
\hline \multicolumn{8}{|l|}{ Corrosion rate $(\mu \mathrm{m} /$ year) for mild steel } \\
\hline Pearson correlation & 1 & $-0.762^{b}$ & $0.476^{\mathrm{b}}$ & $-0.459^{b}$ & $-0.533^{b}$ & 0.072 & 0.199 \\
\hline Significance & & 0.000 & 0.000 & 0.000 & 0.000 & 0.583 & 0.128 \\
\hline $\begin{array}{l}\text { Sum of square and cross } \\
\text { products }\end{array}$ & 9.594 & $-1,574.427$ & 19.517 & -7.046 & -4.031 & 0.148 & 0.366 \\
\hline Covariance & 0.163 & -26.685 & 0.331 & -0.119 & -0.068 & 0.003 & 0.006 \\
\hline $\mathrm{N}$ & 60 & 60 & 60 & 60 & 60 & 60 & 60 \\
\hline \multicolumn{8}{|c|}{ Corrosion rate $(\mu \mathrm{m} / \mathrm{year})$ for stainless steel 316} \\
\hline Pearson correlation & 1 & $0.751^{b}$ & $0.562^{b}$ & $0.901^{b}$ & $0.492^{b}$ & $0.380^{\mathrm{b}}$ & -0.028 \\
\hline Significance & & 0.000 & 0.000 & 0.000 & 0.000 & 0.003 & 0.834 \\
\hline $\begin{array}{l}\text { Sum of square and cross } \\
\text { products }\end{array}$ & 0.251 & 502.032 & 3.722 & 1.082 & 0.568 & 0.043 & -0.002 \\
\hline Covariance & 0.004 & 8.509 & 0.063 & 0.018 & 0.01 & 0.001 & 0 \\
\hline $\mathrm{N}$ & 60 & 60 & 60 & 60 & 60 & 60 & 60 \\
\hline \multicolumn{3}{|c|}{$\begin{array}{c}\text { Dynamic viscosity } \\
\text { at } 40^{\circ} \mathrm{C}\end{array}$} & $\begin{array}{c}\text { Kinematic viscosity } \\
\text { at } 40^{\circ} \mathrm{C}\end{array}$ & $\begin{array}{c}\text { Density at } \\
40^{\circ} \mathrm{C}\end{array}$ & $\begin{array}{c}\text { Density at } \\
15^{\circ} \mathrm{C}\end{array}$ & Acid value & ractive index \\
\hline \multicolumn{8}{|l|}{ Corrosion rate $(\mu \mathrm{m} /$ year) for mild steel } \\
\hline Pearson correlation & \multicolumn{2}{|c|}{0.132} & 0.138 & $0.279^{\mathrm{a}}$ & $0.304^{a}$ & $0.274^{\mathrm{a}}$ & $-0.559^{b}$ \\
\hline Significance & \multicolumn{2}{|c|}{0.313} & 0.293 & 0.031 & 0.018 & 0.034 & 0 \\
\hline Sum of square and cross products & \multicolumn{2}{|c|}{0.372} & 0.435 & 17.956 & 19.65 & 0.538 & -0.025 \\
\hline Covariance & \multicolumn{2}{|c|}{0.006} & 0.007 & 0.304 & 0.333 & 0.009 & 0 \\
\hline $\mathrm{N}$ & & & 60 & 60 & 60 & 60 & 60 \\
\hline Corrosion rate $(\mu \mathrm{m} /$ year) for stainless $s$ & steel 316 & & & & & & \\
\hline Pearson correlation & & & $0.854^{\mathrm{b}}$ & $0.811^{\mathrm{b}}$ & $0.811^{b}$ & $0.867^{b}$ & $-0.363^{b}$ \\
\hline Significance & & & 0.000 & 0.000 & 0.000 & 0.000 & 0.004 \\
\hline Sum of square and cross products & & & 0.618 & 10.703 & 10.702 & 0.311 & -0.003 \\
\hline Covariance & & & 0.01 & 0.181 & 0.181 & 0.005 & 0 \\
\hline $\mathrm{N}$ & & & 60 & 60 & 60 & 60 & 60 \\
\hline
\end{tabular}

${ }^{a}$ Correlation is significant at the 0.05 level (two-tailed).

${ }^{b}$ Correlation is significant at the 0.01 level (two-tailed).

TABLE 8 | Model summary for developing the regression model for mild steel and stainless steel 316 corrosion rate.

\begin{tabular}{llcc}
\hline Specimen & & Mild steel $^{\mathbf{a}}$ & ${\text { Stainless steel } \mathbf{3 1 6}^{\mathbf{b}}}^{\mathbf{b}}$ \\
Model & 12 & 10 \\
$R$ & & 0.931 & 0.975 \\
$R^{2}$ & & 0.867 & 0.950 \\
Adjusted $R^{2}$ & & 0.833 & 0.940 \\
Std. The error of the estimate & 0.1648 & 16.001 \\
Change statistics & $R^{2}$ Change & 0.867 & 0.950 \\
& F Change & 25.528 & 93.170 \\
& df1 & 12 & 10 \\
& df & 47 & 49 \\
& Significance & 0.000 & 0.000 \\
& Durbin-Watson & 1.441 & 1.065
\end{tabular}

Twelve predictors: (constant), day of immersion, blending ratio, weight difference (mg), outer diameter, inner diameter, thickness, dynamic viscosity, kinematic viscosity, density $40^{\circ} \mathrm{C}$, density $15^{\circ} \mathrm{C}$, acid value, and refractive index.

${ }^{a}$ Dependent variable: Corrosion rate of mild steel $(\mu \mathrm{m})$.

Ten predictors: (constant), day of immersion, blending ratio, weight difference (mg), outer diameter, inner diameter, thickness, dynamic viscosity, kinematic viscosity, density $40^{\circ} \mathrm{C}$, and density $15^{\circ} \mathrm{C}$.

${ }^{b}$ Dependent variable: Corrosion rate of stainless steel $316(\mathrm{~nm})$.

\section{Regression Analysis}

Regression analysis was conducted to analyze the potential predictors or variables used to estimate the mild and stainless steel corrosion rate. Table 8 shows the model summary performed to develop a suitable regression model for corrosion rate. The model was developed by adding one variable at each regression modeling. At the end of the modeling process, 12 predictor variables were added into the model, such as day of immersion, blending ratio, weight difference (mg), outer diameter, inner diameter, thickness, dynamic viscosity, kinematic viscosity, density $40^{\circ} \mathrm{C}$, density $15^{\circ} \mathrm{C}$, acid value, and refractive index. The later model shows improvement in $\mathrm{R}$ and $R^{2}$ of 0.931 and 0.867 , respectively. The later model has $86.7 \%$ of variability to predict the corrosion rate of mild steel. The adjusted $R^{2}$ of 0.833 for the later model and the difference between $R^{2}$ and adjusted $R^{2}$ are very small $(0.867-0.833$ $=0.034$ or $3.4 \%$ ). The small difference of $R^{2}$ and adjusted $R^{2}$ model indicates that the model is derived from the population rather than a sample; it would show that the results for the corrosion rate will be $3.4 \%$ less variance. Besides, the 
Durbin-Watson statistic for the later model is 1.441, showing positive autocorrelation in the model formed. The regression model developed by stainless steel is based on 10 independent variables, such as day of immersion, blending ratio, weight difference $(\mathrm{mg})$, outer diameter, inner diameter, thickness, dynamic viscosity, kinematic viscosity, density $40^{\circ} \mathrm{C}$, and density $15^{\circ} \mathrm{C}$ with $R^{2}$ of 0.95 , which means that $95 \%$ of the variability can be explained by the model developed in this study.

\section{CONCLUSION}

The biodiesel was produced from waste cooking oil blended with C. inophyllum oil at a volume ratio of 7:3 using microwave irradiation-assisted alkaline-catalyzed transesterification. The biodiesel produced has high oxidation stability (18.03\%), good pour point of $2^{\circ} \mathrm{C}$, high FAME content of 98.94, and low glyceride content $[<0.4(\mathrm{w} / \mathrm{w}) \%]$. The physicochemical properties of the biodiesel have met the requirements specified in the ASTM D6751 and EN 14214 standards. This study evaluated the compatibility and corrosion study of metallic material immersed in biodiesel-diesel fuel blends.

1. B15-B30 biodiesel-diesel blends affect the carbon steel significantly at $7,200 \mathrm{~h}$ of immersion period; SEM/EDS shows scatter corrosion attack on the specimen, mass loss, and degradation of fuel blends. The highest corrosion rates were $1.9387,2.4234,2.4234,2.1811,2.9081$, and $2.9081 \mathrm{~nm} /$ year for B5-B30, respectively.

2. Stainless steel 316 shows good corrosion resistance in all the biodiesel-diesel fuel blends. At the early stage of the immersion period ( 240 days), no corrosion is formed on the surface with no mass loss. It is found that a passive film formed on the stainless steel 316 surface that has reduced the corrosion attack on the metal's internal structure. The mass loss of the coupon was minimal after prolonged immersion time and high W70CI30 biodiesel concentration in blending ratio (B25-B30), which caused a low corrosion rate. The highest corrosion rates were 0.1062 , $0.1062,0.1417,0.1417,0.1948$, and $0.2125 \mathrm{~nm} /$ year for B5-B30, respectively.

3. Both metallic materials produce their respective oxides in biodiesel due to the presence of free oxygen. The reason for corrosion is the presence of unsaturated fatty acids, free water content, and reactive oxygen atoms. The immersion test method is a beneficial method for corrosion rate measurement.

4. Degradation of the biodiesel-diesel blends can be observed based on the changes in kinematic viscosity, density, reflective index, and acid value. Degradation was found on the acid value

\section{REFERENCES}

Alves, S. M., Dutra-pereira, F. K., and Bicudo, T. C. (2019). Influence of Stainless Steel Corrosion on Biodiesel Oxidative Stability during Storage. Fuel 249, 73-79. doi:10.1016/j.fuel.2019.03.097 for B25 and B30, exceeding the limit stipulated by ASTM D6751 and EN 14214 standards (>0.5 mg KOH/g). The reflective index can be an alternative property to determine biodiesel's degradation.

5. Corrosion occurs on the metallic material and degrades the properties of the biodiesel. Corrosion increases the wear rate of the engine parts in contact with the biodiesel. Therefore, it is important to minimize corrosion attacks when using biodiesel in engines.

6. The regression model shows that the model developed for mild steel and stainless steel 316 has $86.7 \%$ and $95 \%$ variability to predict the corrosion rate. Pearson correlation and covariance between corrosion rate and variables for both mild steel and stainless steel 316 were evaluated.

7. Further studies can be carried out by performing corrosion analysis on other materials to find and study the advantages of other materials that can be used in conjunction with the biodiesel produced. Besides, the electrochemical method can be considered to study the corrosion behavior of metallic materials in various types of fuel blends and feedstock. The electrochemical method will reduce the observation time while determining the corrosion rate. However, the electrochemical methodology should be investigated thoroughly to obtain the same forecasted result as the immersion test.

\section{DATA AVAILABILITY STATEMENT}

The original contributions presented in the study are included in the article/Supplementary Material. Further inquiries can be directed to the corresponding authors.

\section{AUTHOR CONTRIBUTIONS}

JM: experiment and writing-original draft. HU: review and editing. ASh: supervision. ASi: experiment. OI: review and funding. ASe: writing-original draft. IF: review and editing. MM: review and editing.

\section{FUNDING}

This research was supported by the AAIBE Chair of Renewable grant no: 201801. The authors would also like to thank KeTTHA, Malaysia, for supporting this research.

\section{ACKNOWLEDGMENTS}

The authors wish to acknowledge the financial support provided by the Ministry of Education, Culture, Research and Technology and Politeknik Negeri Medan, Medan, Indonesia.

Aquino, I. P., Hernandez, R. P. B., Chicoma, D. L., Pinto, H. P. F., and Aoki, I. V. (2012). Influence of Light, Temperature and Metallic Ions on Biodiesel Degradation and Corrosiveness to Copper and Brass. Fuel 102, 795-807. doi:10.1016/j.fuel.2012.06.011

Brennan, L., and Owende, P. (2010). Biofuels from Microalgae-A Review of Technologies for Production, Processing, and Extractions of Biofuels and 
Co-products. Renew. Sustainable Energ. Rev. 14 (2), 557-577. doi:10.1016/ j.rser.2009.10.009

Cestari, A., de Araújo, M., and de Oliveira, D. C. (2021). Corrosion Behavior of Metallic Surfaces in Biodiesel Evaluated by Atomic Force Microscopy, Vickers Micro Hardness, and Copper Strip Test. Eng. Fail. Anal. 124, 105329. doi:10.1016/j.engfailanal.2021.105329

Chia, S. R., Chew, K. W., Show, P. L., Yap, Y. J., Ong, H. C., Ling, T. C., et al. (2018). Analysis of Economic and Environmental Aspects of Microalgae Biorefinery for Biofuels Production: a Review. Biotechnol. J. 13 (6), 1700618. doi:10.1002/ biot.201700618

Cursaru, D.-L., Brănoiu, G., Ramadan, I., and Miculescu, F. (2014). Degradation of Automotive Materials upon Exposure to sunflower Biodiesel. Ind. Crops Prod. 54, 149-158. doi:10.1016/j.indcrop.2014.01.032

Dalmau, A., Richard, C., and Igual - Muñoz, A. (2018). Degradation Mechanisms in Martensitic Stainless Steels: Wear, Corrosion and Tribocorrosion Appraisal. Tribology Int. 121, 167-179. doi:10.1016/j.triboint.2018.01.036

Damanik, N., Ong, H. C., Chong, W. T., and Silitonga, A. S. (2017). Biodiesel Production from Calophyllum inophyllum-palm Mixed Oil. Energy Sourc. A: Recovery, Utilization, Environ. Effects 39 (12), 1283-1289. doi:10.1080/ 15567036.2017.1324537

Díaz-Ballote, L., López-Sansores, J. F., Maldonado-López, L., and Garfias-Mesias, L. F. (2009). Corrosion Behavior of Aluminum Exposed to a Biodiesel. Electrochemistry Commun. 11 (1), 41-44. doi:10.1016/j.elecom.2008.10.027

Dubey, P., and Gupta, R. (2017). Effects of Dual Bio-Fuel (Jatropha Biodiesel and Turpentine Oil) on a Single cylinder Naturally Aspirated Diesel Engine without EGR. Appl. Therm. Eng. 115, 1137-1147. doi:10.1016/ j.applthermaleng.2016.12.125

Fasogbon, S., and Olagoke, O. (2016). Influence of Temperature on Corrosion Characteristics of Metals in Used Cooking. Oil Methyl Ester 5 (4), 71-75.

Fazal, M. A., Haseeb, A. S. M. A., and Masjuki, H. H. (2010). Comparative Corrosive Characteristics of Petroleum Diesel and palm Biodiesel for Automotive Materials. Fuel Process. Technology 91 (10), 1308-1315. doi:10.1016/j.fuproc.2010.04.016

Fazal, M. A., Haseeb, A. S. M. A., and Masjuki, H. H. (2013). Corrosion Mechanism of Copper in palm Biodiesel. Corrosion Sci. 67, 50-59. doi:10.1016/ j.corsci.2012.10.006

Fazal, M. A., Haseeb, A. S. M. A., and Masjuki, H. H. (2012). Degradation of Automotive Materials in palm Biodiesel. Energy 40 (1), 76-83. doi:10.1016/ j.energy.2012.02.026

Fazal, M. A., Haseeb, A. S. M. A., and Masjuki, H. H. (2011). Effect of Temperature on the Corrosion Behavior of Mild Steel upon Exposure to palm Biodiesel. Energy 36 (5), 3328-3334. doi:10.1016/j.energy.2011.03.028

Fazal, M. A., Jakeria, M. R., Haseeb, A. S. M. A., and Rubaiee, S. (2017). Effect of Antioxidants on the Stability and Corrosiveness of palm Biodiesel upon Exposure of Different Metals. Energy 135, 220-226. doi:10.1016/ j.energy.2017.06.128

Fernandes, D. M., Squissato, A. L., Lima, A. F., Richter, E. M., and Munoz, R. A. A. (2019). Corrosive Character of Moringa Oleifera Lam Biodiesel Exposed to Carbon Steel under Simulated Storage Conditions. Renew. Energ. 139, 1263-1271. doi:10.1016/j.renene.2019.03.034

Folayan, A. J., and Anawe, P. A. L. (2019). Synthesis and Characterization of Argania Spinosa (Argan Oil) Biodiesel by Sodium Hydroxide Catalyzed Transesterification Reaction as Alternative for Petro-Diesel in Direct Injection, Compression Ignition Engines. Heliyon 5 (9), e02427. doi:10.1016/ j.heliyon.2019.e02427

Geller, D. P., Adams, T. T., Goodrum, J. W., and Pendergrass, J. (2008). Storage Stability of Poultry Fat and Diesel Fuel Mixtures: Specific Gravity and Viscosity. Fuel 87 (1), 92-102. doi:10.1016/j.fuel.2007.03.043

Goh, B. H. H., Ong, H. C., Cheah, M. Y., Chen, W.-H., Yu, K. L., and Mahlia, T. M. I. (2019). Sustainability of Direct Biodiesel Synthesis from Microalgae Biomass: A Critical Review. Renew. Sustainable Energ. Rev. 107, 59-74. doi:10.1016/ j.rser.2019.02.012

Gulzar, M., Masjuki, H. H., Varman, M., Kalam, M. A., Zulkifli, N. W. M., Mufti, R. A., et al. (2016). Effects of Biodiesel Blends on Lubricating Oil Degradation and Piston Assembly Energy Losses. Energy 111, 713-721. doi:10.1016/ j.energy.2016.05.132

Halimatussadiah, A., Nainggolan, D., Yui, S., Moeis, F. R., and Siregar, A. A. (2021). Progressive Biodiesel Policy in Indonesia: Does the Government's Economic
Proposition Hold? Renew. Sustainable Energ. Rev. 150, 111431. doi:10.1016/ j.rser.2021.111431

Haseeb, A. S. M. A., Masjuki, H. H., Ann, L. J., and Fazal, M. A. (2010). Corrosion Characteristics of Copper and Leaded Bronze in palm Biodiesel. Fuel Process. Technology 91 (3), 329-334. doi:10.1016/j.fuproc.2009.11.004

Hazrat, M., Rasul, M., Khan, M., Mofijur, M., Ahmed, S., Ong, H. C., et al. (2021). Techniques to Improve the Stability of Biodiesel: a Review. Environ. Chem. Lett., 1-28. doi:10.1007/s10311-020-01166-8

Hu, E., Xu, Y., Hu, X., Pan, L., and Jiang, S. (2012). Corrosion Behaviors of Metals in Biodiesel from Rapeseed Oil and Methanol. Renew. Energ. 37 (1), 371-378. doi:10.1016/j.renene.2011.07.010

Issariyakul, T., and Dalai, A. K. (2014). Biodiesel from Vegetable Oils. Renew. Sustainable Energ. Rev. 31, 446-471. doi:10.1016/j.rser.2013.11.001

Jain, S., and Sharma, M. P. (2011). Thermal Stability of Biodiesel and its Blends: A Review. Renew. Sustainable Energ. Rev. 15 (1), 438-448. doi:10.1016/ j.rser.2010.08.022

Jin, D., Zhou, X., Wu, P., Jiang, L., and Ge, H. (2015). Corrosion Behavior of ASTM 1045 Mild Steel in palm Biodiesel. Renew. Energ. 81, 457-463. doi:10.1016/ j.renene.2015.03.022

Kaul, S., Saxena, R. C., Kumar, A., Negi, M. S., Bhatnagar, A. K., Goyal, H. B., et al. (2007). Corrosion Behavior of Biodiesel from Seed Oils of Indian Origin on Diesel Engine Parts. Fuel Process. Technology 88 (3), 303-307. doi:10.1016/ j.fuproc.2006.10.011

Khatiwada, D., Palmén, C., and Silveira, S. (2018). Evaluating the palm Oil Demand in Indonesia: Production Trends, Yields, and Emerging Issues. Biofuels 12, 135-147. doi:10.1080/17597269.2018.1461520

Kim, G. (2019). Annual, China-Biofuels. Washington, DC: USDA-Foreign Agricultural Service. Global Agricultural Information Network (GAIN), GAIN Report Number: CN19047".).

Komariah, L. N., Arita, S., Prianda, B. E., and Dewi, T. K. (2021). Technical Assessment of Biodiesel Storage Tank; A Corrosion Case Study. Riyadh, Saudi Arabia: Journal of King Saud University-Engineering Sciences.

Kugelmeier, C. L., Monteiro, M. R., da Silva, R., Kuri, S. E., Sordi, V. L., and Della Rovere, C. A. (2021). Corrosion Behavior of Carbon Steel, Stainless Steel, Aluminum and Copper upon Exposure to Biodiesel Blended with Petrodiesel. Energy 226, 120344. doi:10.1016/j.energy.2021.120344

Kusumo, F., Silitonga, A. S., Masjuki, H. H., Ong, H. C., Siswantoro, J., and Mahlia, T. M. I. (2017). Optimization of Transesterification Process for Ceiba Pentandra Oil: A Comparative Study between Kernel-Based Extreme Learning Machine and Artificial Neural Networks. Energy 134, 24-34. doi:10.1016/j.energy.2017.05.196

Lee, X. J., Ong, H. C., Gan, Y. Y., Chen, W.-H., and Mahlia, T. M. I. (2020). State of Art Review on Conventional and Advanced Pyrolysis of Macroalgae and Microalgae for Biochar, Bio-Oil and Bio-Syngas Production. Energ. Convers. Management 210, 112707. doi:10.1016/j.enconman.2020.112707

Lin, B.-J., Chen, W.-H., Hsieh, T.-H., Ong, H. C., Show, P. L., and Naqvi, S. R. (2019). Oxidative Reaction Interaction and Synergistic index of Emulsified Pyrolysis Bio-Oil/diesel Fuels. Renew. Energ. 136, 223-234. doi:10.1016/ j.renene.2018.12.111

Lu, Q., Zhang, J., and Zhu, X. (2008). Corrosion Properties of Bio-Oil and its Emulsions with Diesel. Chin. Sci. Bull. 53 (23), 3726-3734. doi:10.1007/s11434008-0499-7

Malpass, G. R. P., and Motheo, A. J. (2003). The Galvanostatic Oxidation of Aldehydes to Acids on Ti/Ru0.3Ti0.7O2 Electrodes Using a Filter-Press Cell. J. Braz. Chem. Soc. 14, 65-70. doi:10.1590/s010350532003000100011

Mat Aron, N. S., Khoo, K. S., Chew, K. W., Show, P. L., Chen, W. H., and Nguyen, T. H. P. (2020). Sustainability of the Four Generations of Biofuels - A Review. Int. J. Energ. Res 44 (12), 9266-9282. doi:10.1002/er.5557

Milano, J., Ong, H. C., Masjuki, H. H., Chong, W. T., Lam, M. K., Loh, P. K., et al. (2016). Microalgae Biofuels as an Alternative to Fossil Fuel for Power Generation. Renew. Sustainable Energ. Rev. 58, 180-197. doi:10.1016/ j.rser.2015.12.150

Milano, J., Ong, H. C., Masjuki, H. H., Silitonga, A. S., Chen, W.-H., Kusumo, F., et al. (2018a). Optimization of Biodiesel Production by Microwave IrradiationAssisted Transesterification for Waste Cooking Oil-Calophyllum Inophyllum Oil via Response Surface Methodology. Energ. Convers. Management 158, 400-415. doi:10.1016/j.enconman.2017.12.027 
Milano, J., Ong, H. C., Masjuki, H. H., Silitonga, A. S., Kusumo, F., Dharma, S., et al. (2018b). Physicochemical Property Enhancement of Biodiesel Synthesis from Hybrid Feedstocks of Waste Cooking Vegetable Oil and Beauty Leaf Oil through Optimized Alkaline-Catalysed Transesterification. Waste Management 80, 435-449. doi:10.1016/j.wasman.2018.09.005

Mofijur, M., Atabani, A. E., Masjuki, H. H., Kalam, M. A., and Masum, B. M. (2013a). A Study on the Effects of Promising Edible and Non-edible Biodiesel Feedstocks on Engine Performance and Emissions Production: A Comparative Evaluation. Renew. Sustainable Energ. Rev. 23, 391-404. doi:10.1016/ j.rser.2013.03.009

Mofijur, M., Masjuki, H. H., Kalam, M. A., and Atabani, A. E. (2013b). Evaluation of Biodiesel Blending, Engine Performance and Emissions Characteristics of Jatropha Curcas Methyl Ester: Malaysian Perspective. Energy 55, 879-887. doi:10.1016/j.energy.2013.02.059

Monirul, I. M., Masjuki, H. H., Kalam, M. A., Zulkifli, N. W. M., Rashedul, H. K., Rashed, M. M., et al. (2015). A Comprehensive Review on Biodiesel Cold Flow Properties and Oxidation Stability along with Their Improvement Processes. RSC Adv. 5 (105), 86631-86655. doi:10.1039/c5ra09555g

Moser, B. R. (2009). Biodiesel Production, Properties, and Feedstocks. In Vitro Cell.Dev.Biol.-Plant 45, 229-266. doi:10.1007/s11627-009-9204-Z

Nautiyal, P., Subramanian, K. A., Dastidar, M. G., and Kumar, A. (2020). Experimental Assessment of Performance, Combustion and Emissions of a Compression Ignition Engine Fuelled with Spirulina Platensis Biodiesel. Energy 193, 116861. doi:10.1016/j.energy.2019.116861

Ong, H. C., Milano, J., Silitonga, A. S., Hassan, M. H., Shamsuddin, A. H., Wang, C.-T., et al. (2019). Biodiesel Production from Calophyllum Inophyllum-Ceiba Pentandra Oil Mixture: Optimization and Characterization. J. Clean. Prod. 219, 183-198. doi:10.1016/j.jclepro.2019.02.048

Ononiwu, G. I., Adams, F. V., Joseph, I. V., and Afolabi, A. S. (2015). "Corrosion Behaviour of Mild Steel in Biodiesel Prepared from Ghee Butter," in 2015 World Congress on Engineering, WCE 2015, London, UK, July 1-3, 2015, 1-5.

Rashed, M. M., Kalam, M. A., Masjuki, H. H., Mofijur, M., Rasul, M. G., and Zulkifli, N. W. M. (2016). Performance and Emission Characteristics of a Diesel Engine Fueled with palm, Jatropha, and Moringa Oil Methyl Ester. Ind. crops Prod. 79, 70-76. doi:10.1016/j.indcrop.2015.10.046

Riayatsyah, T. M. I., Ong, H. C., Chong, W. T., Aditya, L., Hermansyah, H., and Mahlia, T. M. I. (2017). Life Cycle Cost and Sensitivity Analysis of Reutealis Trisperma as Non-edible Feedstock for Future Biodiesel Production. Energies 10 (7), 877. doi:10.3390/en10070877

Román, A. S., Méndez, C. M., and Ares, A. E. (2020). "Corrosion Resistance of Stainless Steels in Biodiesel," in Shape Casting: 6th International Symposium (Springer), 109-116. doi:10.1007/978-3-319-48166-1_14

Sánchez-Arreola, E., Bach, H., and Hernández, L. R. (2019). Biodiesel Production from Cascabela Ovata Seed Oil. Bioresour. Technology Rep. 7, 100220. doi:10.1016/j.biteb.2019.100220

Sarin, R., Arora, A. K., Ranjan, R., Gupta, A. A., and Malhotra, R. K. (2007). Biodiesel Lubricity: Correlation Study with Residual Acidity. Lubrication Sci. 19 (2), 151-157. doi:10.1002/ls.40

Shehzad, A., Ahmed, A., Quazi, M. M., Jamshaid, M., Ashrafur Rahman, S. M., Hassan, M. H., et al. (2021). Current Research and Development Status of Corrosion Behavior of Automotive Materials in Biofuels. Energies 14 (5), 1440. doi:10.3390/en 14051440

Shekofteh, M., Gundoshmian, T. M., Jahanbakhshi, A., and Heidari-Maleni, A. (2020). Performance and Emission Characteristics of a Diesel Engine Fueled with Functionalized Multi-wall Carbon Nanotubes (MWCNTs-OH) and Diesel-Biodiesel-Bioethanol Blends. Energ. Rep. 6, 1438-1447. doi:10.1016/ j.egyr.2020.05.025

Siddiki, S. Y. A., Mofijur, M., Kumar, P. S., Ahmed, S. F., Inayat, A., Kusumo, F., et al. (2022). Microalgae Biomass as a Sustainable Source for Biofuel,
Biochemical and Biobased Value-Added Products: An Integrated Biorefinery Concept. Fuel 307, 121782. doi:10.1016/j.fuel.2021.121782

Silitonga, A. S., Mahlia, T. M. I., Kusumo, F., Dharma, S., Sebayang, A. H., Sembiring, R. W., et al. (2019). Intensification of Reutealis Trisperma Biodiesel Production Using Infrared Radiation: Simulation, Optimisation and Validationfication of Reutealis Trisperma Biodiesel Production Using Infrared Radiation: Simulation, Optimisation and Validation. Renew. Energ. 133, 520-527. doi:10.1016/j.renene.2018.10.023

Silva de Sousa, L., de Moura, C. V. R., and de Moura, E. M. (2020). Influence of Binary, Ternary and Quaternary Mixtures on Oxidative Stability and Study of Kinetics and Thermodynamic Parameters of the Degradation Process of Soybean Biodiesel. Fuel 259, 116235. doi:10.1016/ j.fuel.2019.116235

Singh, B., Korstad, J., and Sharma, Y. C. (2012). A Critical Review on Corrosion of Compression Ignition (CI) Engine Parts by Biodiesel and Biodiesel Blends and its Inhibition. Renew. Sustainable Energ. Rev. 16 (5), 3401-3408. doi:10.1016/ j.rser.2012.02.042

SupriyonoSulistyo, H., Almeida, M. F., and Dias, J. M. (2015). Influence of Synthetic Antioxidants on the Oxidation Stability of Biodiesel Produced from Acid Raw Jatropha Curcas Oil. Fuel Process. Technology 132, 133-138. doi:10.1016/j.fuproc.2014.12.003

Thangarasu, V., Balaji, B., and Ramanathan, A. (2019). Experimental Investigation of Tribo-Corrosion and Engine Characteristics of Aegle Marmelos Correa Biodiesel and its Diesel Blends on Direct Injection Diesel Engine. Energy 171, 879-892. doi:10.1016/j.energy.2019.01.079

Wang, W., Jenkins, P. E., and Ren, Z. (2012). Electrochemical Corrosion of Carbon Steel Exposed to Biodiesel/simulated Seawater Mixture. Corrosion Sci. 57, 215-219. doi:10.1016/j.corsci.2011.12.015

Wei, J., and Wang, Y. (2021). Effects of Biodiesels on the Physicochemical Properties and Oxidative Reactivity of Diesel Particulates: A Review. Sci. Total Environ. 788, 147753. doi:10.1016/j.scitotenv.2021.147753

Xue, Y., Zhao, Z., Xu, G., Lian, X., Yang, C., Zhao, W., et al. (2016). Effect of PolyAlpha-Olefin Pour point Depressant on Cold Flow Properties of Waste Cooking Oil Biodiesel Blends. Fuel 184, 110-117. doi:10.1016/j.fuel.2016.07.006

Yang, X. B., Chen, J. H., Zhang, G. H., Huang, L. P., Fan, T. W., Ding, Y., et al. (2018). A Transmission Electron Microscopy Study of Microscopic Causes for Localized-Corrosion Morphology Variations in the AA7055 Al alloy. J. Mater. Sci. Technology 34 (10), 1719-1729. doi:10.1016/j.jmst.2018.05.006

Zahan, K., and Kano, M. (2018). Biodiesel Production from Palm Oil, its ByProducts, and Mill Effluent: A Review. Energies 11 (8), 2132. doi:10.3390/ en 11082132

Conflict of Interest: The authors declare that the research was conducted in the absence of any commercial or financial relationships that could be construed as a potential conflict of interest.

Publisher's Note: All claims expressed in this article are solely those of the authors and do not necessarily represent those of their affiliated organizations, or those of the publisher, the editors, and the reviewers. Any product that may be evaluated in this article, or claim that may be made by its manufacturer, is not guaranteed or endorsed by the publisher.

Copyright (c) 2021 Milano, Umar, Shamsuddin, Silitonga, Irfan, Sebayang, Fattah and Mofijur. This is an open-access article distributed under the terms of the Creative Commons Attribution License (CC BY). The use, distribution or reproduction in other forums is permitted, provided the original author(s) and the copyright owner(s) are credited and that the original publication in this journal is cited, in accordance with accepted academic practice. No use, distribution or reproduction is permitted which does not comply with these terms. 